Arqueología y Sociedad,

№ 23, 2011

\title{
RAZA, GÉNERO Y CULTURA en las aCUarelas de Pancho Fierro
}

Maribel Arrelucea Barrantes*

\section{Resumen}

Este artículo toma las acuarelas de Pancho Fierro como fuente histórica para entrar al estudio de la unidad y circularidad cultural, más que la diferencia, entre la sociedad colonial, de orden estamental, y la republicana de la primera mitad del siglo XIX.

\section{Palabras clave}

Liberalismo, esclavitud, Pancho Fierro, cultura popular, afroperuanas, razas, zamacueca, mujeres.

\begin{abstract}
This article takes the watercolors of Pancho Fierro ask a historical source to enter the study of cultural unity and circularity, more than the different, bewteen the colonial society, order estates, and Republican in the first half of the ninetheenth Century.
\end{abstract}

\section{Keywords}

Liberalism, slavery, Pancho Fierro, popular culture, afroperuvian, races, zamacueca, women.

* Magister en Historia por la Universidad Nacional Mayor de San Marcos, docente de la Universidad de Lima. Ha publicado numerosos artículos en revistas y compilaciones nacionales y extranjeras, también es autora del libro Replanteando la esclavitud. Estudios de etnicidad y género en Lima borbónica. Lima, Centro de Desarrollo Étnico- CEDET, Centro Cultural de España-AECID, 2009.

Correo electrónico: cimarronasola_33@hotmail.com 


\section{INTRODUCCIÓN}

La primera vez que observé unas acuarelas de Pancho Fierro era apenas una niña, pero aún a la distancia recuerdo nítidamente los colores brillantes, las siluetas de las tapadas y las vendedoras de frutas. Luego, conforme pasaron los años, las acuarelas se convirtieron en parte de mi formación escolar, las encontraba en mis libros, las láminas y hasta en las Tradiciones peruanas de Ricardo Palma. Para mí, el pasado colonial y decimonónico estaba pintado en los suaves colores de las acuarelas panchofierristas.

Volví a encontrarme con Pancho Fierro mientras investigaba sobre los esclavos limeños, descubrí que buena parte de las publicaciones especializadas en esclavitud colonial y republicana contiene las acuarelas atribuidas a Pancho Fierro. El asunto es que existen pocas fuentes iconográficas sobre la esclavitud en el Perú, es más fácil encontrar a los esclavos en las fuentes escritas como las referencias de viajeros, las memorias, los expedientes judiciales y hasta en los documentos de aduanas pero las imágenes son escasas. Para imaginarnos cómo lucían los hombres y mujeres esclavos de Lima o cualquier sitio del Perú colonial nos debemos remitir a las clásicas imágenes de Guamán Poma de Ayala, el obispo Martínez Compañón y Pancho Fierro.

Quisiera empezar por trazar la línea general de reflexión que direcciona esta investigación. No me interesan las acuarelas por ser elaboradas por Pancho Fierro, tampoco discutir la autenticidad de las mismas, si son falsas o copias seriadas. Las investigaciones de Cisneros y, sobretodo, Majluf, han demostrado que el Costumbrismo fue un estilo local, costeño y latinoamericano ${ }^{1}$, bajo una fuerte tradición europea, existieron pintores que sentaron un precedente, otros retomaron el estilo, después de las guerras de Independencia y durante buena parte del siglo XIX los latinoamericanos consumieron imágenes seriadas, por lo general en acuarelas, luego trasladadas a la fotografía, repitiendo los mismos tipos y las costumbres como el aguador, la lechera, las vendedoras, las procesiones, los toros, los gallos, los carnavales, las fiestas, entre otros.

1 Manuel Cisneros (1975), Natalia Majluf (2008)
Así que, para mí, las acuarelas forman parte de un universo simbólico que prefiero identificar como "estilo panchofierrista" por ser Pancho Fierro su máximo exponente y el más popular, pero que designa también a sus clientes, amigos, coleccionistas y admiradores, una inmensa red de relaciones sociales y culturales ${ }^{2}$ que compartían algo más que el gusto por las acuarelas. Los textos escritos y las imágenes panchofierristas deben ser leídos como un conjunto de discursos, distintos pero contemporáneos, sobre la nación, el país, la geografía, la ciudad, el género y la raza.

También soy consciente que trabajar con imágenes conlleva una serie de consideraciones hermenéuticas. Para empezar, como bien advierte Burke, los pintores, al igual que los fotógrafos, reproducen la sociedad escogiendo individuos, escenas, grupos, ángulos concretos elegidos por ellos porque creen que son tipos representativos ${ }^{3}$.

Las acuarelas de Pancho Fierro, o mejor dicho, las acuarelas panchofierristas ${ }^{4}$, deben ser vistas y valoradas dentro del conjunto de imágenes visuales y literarias que se produjeron en el siglo XIX pero de ninguna manera pienso que son documentos exactos de la época, que reflejan la verdad absoluta, hay un tono satírico en muchas de las acuarelas que se deben tomar en cuenta, así como las idealizaciones, y en el otro extremo, miradas grotescas que no debemos perder de vista, pero todo en conjunto evidencia un discurso, o mejor dicho, discursos que hablan sobre las mujeres, los hombres, las

2 Para Deborah Poole ver y representar son actos "materiales" en la medida en que constituyen medios de intervenir en el mundo, estos actos son individuales y sociales porque se elaboran dentro de redes sociales. Deborah Poole (2000: 4)

3 Coincido con este autor al afirmar que una imagen es una opinión pintada, una visión de la sociedad en un sentido ideológico y visual. Peter Burke (2001: 152)

$4 \mathrm{Al}$ no tomar en cuenta el problema de la autenticidad, mi investigación estuvo más libre de trabajar con acuarelas publicadas en distintos medios como los de Cisneros (1975), Natalia Majluf (2008), Caller (2003) y la Municipalidad de Lima (2005) Agradezco profundamente el apoyo entusiasta de Claudia Juárez y Ernesto Pajares en la búsqueda de las acuarelas. 


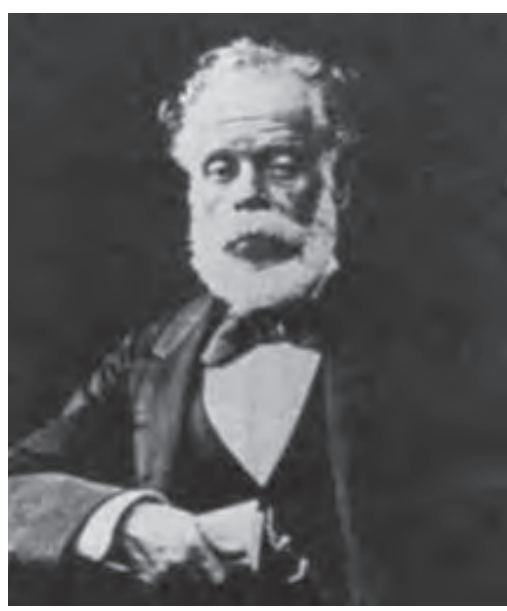

Fotografía de Pancho Fierro. Archivo Courret. Reproducido en Majluf, Natalia y Marcus B. Burke, "Tipos del Perú. La Lima criolla de Pancho Fierro". Madrid, Ediciones El Viso, 2008.

\section{Retrato de Pancho Fierro por Nicolás Palas (1888) \\ Museo Nacional de la Cul- tura Peruana, Lima.}

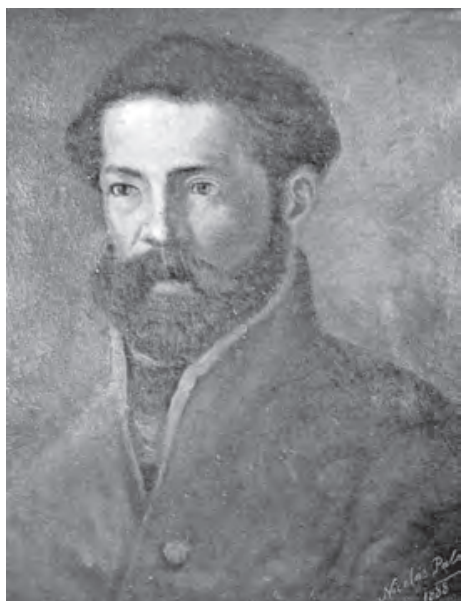

relaciones sociales, las mentalidades, creencias, emociones, jerarquías, miedos y odios.

\section{Pancho Fierro,}

\section{UN HOMBRE ENTRE DOS MUNDOS}

Sin duda alguna Pancho Fierro es y seguirá siendo un enigma, una leyenda esquiva para la historia, desde los detalles de su vida hasta su propio rostro. La fotografía del Archivo Courret nos dejó la imagen de un hombre afro, culto y elegante con un libro en la mano, mayor, con una mirada serena. Nicolás Palas pintó un retrato de Fierro en 1888, como parte de una serie sobre intelectuales y artistas peruanos encargada por la Biblioteca Nacional. Ahora bien, este retrato fue hecho varios años después de su muerte, por lo tanto debió realizarse apelando a la memoria del pintor Palas quien además si conoció a Fierro y al igual que la fotografía, nos devuelve un rostro serio, de mirada reposada aunque mucho más joven y más mestizo, menos negro. Ambos retratos nos dan una imagen oficial de Fierro, serio, culto, muy cercano al ideal de la elite limeña moderna, disciplinada y europeizada.

En el otro extremo, circulan interesantes anécdotas contadas por algunas personas que lo conocieron que apuntan más bien a un hombre con espíritu jaranero, festivo, relajado, más cercano a la esencia limeña. En particular, me refiero a Acisclo Villarán e Ismael Portal que lo conocieron y fueron sus amigos, Villarán lo llamaba "hombre de bronce" y aseguraba que era galante, educado, muy atento y obsequioso mientras que Portal hace énfasis en sus habilidades para seducir a las mujeres, genio y agudeza ${ }^{5}$.

Manuel Cisneros deja correr su imaginación y señala la posibilidad de la existencia de un retrato directo de Pancho Fierro pintado por Ignacio Merino ${ }^{6}$. Presume que Fierro fue el modelo para el personaje central del óleo La jarana, elaborado antes de 1850. El hombre es representado como un mulato con la camisa desabotonada que deja al descubierto el pecho, cabellera abundante y suelta, tienen barba, mirada penetrante y actitud sensual, coincidente con las descripciones dejadas por Villarán y Portal. La amistad entre Merino, el pintor al óleo y Fierro, el pintor acuarelista, está confirmada fehacientemente, trabajaron juntos en una serie de acuarelas pintadas entre 1838 y 1839. Además, Merino llevó a Europa numerosas acuarelas de Fierro que tuvieron mucho éxito, según comentó después Carlos Augusto Salaverry, amigo de Merino?

5 Villarán escribió sus recuerdos sobre Pancho Fierro en el Semanario La Broma (1878) y Portal en sus libros que evocan una Lima aristocrática y sensual (1919, 1932, 1912) A propósito, Portal conoció a Fierro, ya anciano, en su casa de la calle Plateros de San Agustín. Porras (1959: 15)

6 Manuel Cisneros (1975: 25)

7 Referencia de Manuel Cisneros (1975: 25-26) Ignacio Merino perteneció a la elite limeña, se educó en Europa y tuvo un papel protagónico en la pintura peruana junto con Francisco Lazo. 


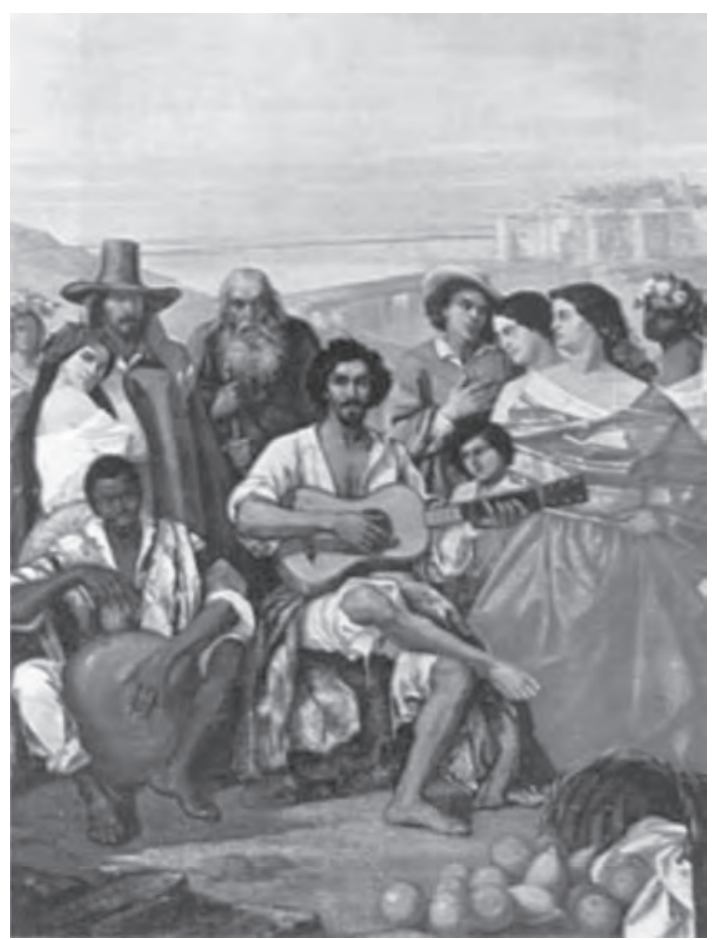

Pero mi investigación no pretende reconstruir la vida privada de Pancho Fierro ni hacer un inventario de su vasta obra pictórica, esos aspectos me interesan en tanto ayudan a entender al sujeto histórico, mi propósito es reconstruir los discursos estéticos que Pancho Fierro plasmó en sus acuarelas porque constituye otra forma de entrar al complejo mundo de los símbolos culturales del siglo XIX peruano. A través de sus acuarelas podemos percibir sus gustos y pasiones como hombre, pintor, mulato, limeño, así como también acercarnos a las simbologías de sus clientes y amigos, un sector representativo de la sociedad limeña. Es verdad que nadie como él supo captar con ironía y gracia los modelos estéticos predominantes, los discursos sobre las mujeres y finalmente, la cultura costeña y limeña.

Pancho Fierro fue un hombre extraordinario, testigo envidiable del siglo XIX, vivió los grandes acontecimientos de la historia peruana, entre los últimos tiempos del Virreinato, el establecimiento de la República y la Guerra con Chile. Podría afirmarse que su existencia estuvo marcada por una muerte simbólica, nació en

\section{Ignacio Merino, La Jarana}

plena agonía del Virreinato y su propia muerte, un 28 de julio de 1879, Día de la Independencia peruana, coincidió con la crisis/muerte del Estado republicano inicial ${ }^{8}$.

Por eso es importante situar a Pancho Fierro en el tiempo y espacio, yo distingo tres grandes etapas en su trabajo, la primera transcurre entre las décadas de los 20 y 30, es decir, entre el Virreinato y la Independencia, la segunda corresponde a las décadas del 40 y 50, durante el apogeo económico que experimentó el Perú gracias a la explotación del guano, la tercera etapa corresponde al clima de crisis económica que antecedió a la Guerra con Chile. La inmensa obra de Pancho Fierro debe ser entendida sincrónicamente con los vaivenes de la historia peruana para apreciar los cambios y continuidades culturales del pintor y la sociedad en su conjunto.

El punto inicial de Pancho Fierro fue la primera década del siglo XIX, en la cual el Virreinato peruano funcionaba plenamente, nada presagiaba una ruptura posterior. Como bien sabemos, la infancia es de suma importancia para moldear conciencias, afectos, gustos y valores, el niño Pancho Fierro fue educado bajo los códigos del mundo colonial y sus acuarelas reflejan esa mirada hacia un pasado que no era tan lejano ni diferente porque la Independencia peruana, sucedida entre 1821 y 1824 , no fue traumática o radical, más bien fue un proceso lento, con más continuidades culturales de lo que pensamos.

Así como Pancho Fierro fue un hombre de mentalidad, costumbres y gustos coloniales que pasó lentamente a vivir los tiempos republica-

8 Pancho Fierro sigue siendo un misterio como sujeto histórico, durante la mayor parte del siglo XX sus biógrafos apenas daban algunos datos hasta la prolija investigación de Gustavo León (2004). Sin embargo, el pintor sigue evadiendo a la historia pues nadie puede explicar cómo transcurrió su infancia, cómo aprendió a pintar, qué maestros lo guiaron, quiénes influyeron en su obra, quiénes fueron sus amigos, entre otros aspectos importantes de su existencia. Esto era bastante típico en una sociedad tradicional como la peruana, los datos biográficos no importaban mucho, más aún cuando se trataba de los sectores populares y con mayor énfasis cuando eran esclavos o libertos. 
nos, también sucedió otro tanto con la sociedad peruana. Este punto es de vital importancia para volver a apreciar esa mirada al pasado colonial que algunos han catalogado como "nostálgica" y otros podrían tildar de ahistórica.

Lo que aprecio es una generación de hombres formada bajo los patrones culturales del mundo colonial, vivían y sentían bajo esos códigos, pero después el presente se tornó inestable por el contexto de guerra permanente e indecisiones políticas, en especial Lima, el bastión realista por excelencia. Como bien ha remarcado una renovada historiografía especializada, ${ }^{9}$ la guerra de Independencia no culminó con un Estado republicano estable, todo lo contrario, se desataron las luchas caudillistas que prolongaron el clima de guerra por eso me parece que surgió la "nostalgia", un mecanismo de defensa frente al presente incierto, el pasado colonial fue visto como un pasado reciente mejor, un mundo feliz, una arcadia.

El mismo Ricardo Palma exclama numerosas frases de nostalgia en sus Tradiciones, por ejemplo, en la tradición "Los escrúpulos de Halicarnaso" cuenta sobre los estudiantes carolinos y de pronto intercala una frase de nostalgia: "! Ah tiempos aquellos! La boca se me hace agua al recordarlos. Los colegiales no formábamos meetings políticos, ni entrábamos en clubs eleccionarios, ni pretendíamos dar la ley y gobernar al gobierno"10.

Entre las guerras de Independencia y la post guerra del Pacífico tenemos un complejo proceso cultural dirigido por hombres que escribieron tradiciones y piezas de teatro, pintaron los cuadros de costumbres, mantuvieron las diversiones, las bebidas, las comidas y la música tradicional, no se trataba de crear algo nuevo, se trataba de defender algo que consideraban suyo, en este caso el pasado colonial que a su vez era también el pasado personal, la infancia perdida. Pienso que también estaban reaccionando con miedo ante un futuro inquietante que no se definía aún, las luchas caudillistas prolongaron la inestabilidad, no se avi-

9 Ver por ejemplo el reciente libro de Juan Orrego, Cristóbal Aljovin e Ignacio López Soria (2009)

10 Ricardo Palma (1921: 103) zoraba un futuro promisorio hasta el apogeo de los años 40 y 50 que también se truncó bastante rápido y se pasó a una larga coyuntura de agonía económica y política que tocó su punto más bajo en la Guerra del Pacífico (1879) y se prolongó después hasta casi terminar el siglo XIX. Podría afirmar, sin dudar, que Pancho Fierro junto a los hombres de su generación pasaron bruscamente de una infancia feliz a un siglo angustiante, igual que el Perú.

Considero que este punto es relevante porque la angustia por el presente y el futuro los llevó a construir una imagen ideal del mundo colonial: para todos ellos el pasado era feliz, sin problemas ni angustias, inmutable, eterno, sin cambios, fabricada de antemano, sin inicio ni final, vigente ${ }^{11}$.

Por otro lado, Pancho Fierro fue, en vida, un pintor admirado, sus contemporáneos nos hablan de un mulato jaranero, enamorador, galante, bebedor, divertido. Se sabe que tenía admiradores como Ricardo Palma, Segismundo Jacoby, Nicolás Dora, Francisco García Calderón, Federico Elguera, José Antonio de Lavalle, entre otros, quienes formaron sus propias colecciones de estampas ${ }^{12}$. Algunos extranjeros llevaron sus

11 Esta mirada ideal del mundo colonial coincide en muchos rasgos con la historiografía griega y romana, para Collingwood el sustancialismo implica una teoría del conocimiento según lo cual sólo lo inmutable es cognocible, pero lo inmutable no es histórico, lo histórico es el suceso transitorio. Collingwood (1996: 50-52).

12 Francisco García Calderón fue Presidente Provisorio del Perú durante la Guerra con Chile y formó una colección de ciento treinta y ocho acuarelas, al viajar a Europa, exiliado, compró ochenta y nueve acuarelas más que después donó a su hijo Ventura García Calderón, célebre escritor. José Antonio de Lavalle, escritor, político y diplomático, formó su colección por compra directa y por obsequio de Federico Elguera, Alcalde de Lima a inicios del siglo XX. Segismundo Jacoby fue un comerciante judío de origen alemán, estableció una Casa de Cambio en Lima, banquero, joyero y prestamista, para Cisneros probablemente fue mecenas de Pancho Fierro, coleccionó algo de doscientas seis acuarelas. Nicolás Dora, comerciante suizo y copropietario de la célebre confitería, dulcería, heladería y licorería Broggi hermanos y Dora, reunió más de cien acuarelas, Nicolás Dora apreciaba mucho a Fierro y colaboró con su entierro. Gustavo León (2004: 25-27). 
acuarelas a otros países, como Leonce Angrand, cónsul francés en el Perú y Bolivia entre 1836 y 1860 aproximadamente, quien dejó un valioso apunte sobre Fierro a quien recuerda como un mulato que nunca aprendió a pintar pero que logró plasmar con asombrosa exactitud los tipos humanos y costumbres ${ }^{13}$. Asimismo, Leopoldo Schrenck, jefe de la expedición científica de la fragata "Aurora" visitó Perú en 1854, en Lima conversó con el sabio Antonio Raimondi en los ambientes de la antiquísima Universidad San Marcos, también conoció al intelectual y político Francisco González Vigil y estando en el célebre Almacén Ricordi adquirió algunas acuarelas de Pancho Fierro que llevó a la lejana Rusia ${ }^{14}$.

Hombres como Ricardo Palma, Agustín de la Rosa Toro, José Antonio de Lavalle, Manuel Segura, Pancho Fierro, entre otros fueron contemporáneos, vieron la misma ciudad, compartieron las angustias de su tiempo, hay más vínculos y sentimientos comunes entre ellos que escapan del escrutinio histórico, pero vale la pena reconstruirlos porque forman parte de un periodo trascendental, la formación de la nación republicana que ellos construyeron a su modo, bajo sus propios lenguajes, símbolos y discursos. Apenas quedan algunas referencias fragmentadas, como una carta enviada por Agustín de la Rosa Toro a Ricardo Palma, ambos grandes coleccionistas de las acuarelas de Pancho Fierro. En ella, Agustín de La Rosa Toro afirma

Mi afición a las antigüedades históricas me determinó desde hace algunos años formar una colección de cuadritos a la aguada, que ha indicación mía iba produciendo el conocido

13 Sobre los pintores extranjeros que visitaron el Perú en el Novecientos ver Cisneros (1975: 56-80) En el siglo XIX pintar al óleo era mucho más refinado que la acuarela, considerada como un arte menor, de allí que Angrand se refiere a Fierro como alguien que "nunca aprendió a pintar" porque no lo hacía bajo los cánones formales y europeos.

14 Boris Lukin (2003: 3) Las acuarelas de Angrand se conservan en la Biblioteca Nacional de París y las de Schrenck en la Sección Leningradense del Archivo de la Academia de Ciencias de Rusia. También hay acuarelas atribuidas a Fierro en Alemania, Estados Unidos, Argentina y Brasil. pincel de Pancho Fierro, para con ellos avivar el recuerdo de los trajes, usos, costumbres e instituciones de la época colonial en nuestro país, a fin de que pudieran servir de boceto para ilustrar los estudios etnográficos y sobre todo para comenzar algún día entre nosotros la pintura histórica ${ }^{15}$.

Tomando en cuenta esas reflexiones, deberíamos dejar la historia fragmentada porque considero que no es sólo la pintura que representa tipos y escenas populares urbanas, una mirada totalizadora, permitiría reconstruir finalmente cómo se construyó la nación peruana desde la literatura, en especial el género de las tradiciones, cuyo máximo exponente fue Ricardo Palma, gran admirador de Pancho Fierro, también destaca el teatro costumbrista, como el de Manuel A. Segura, así como otros aspectos culturales cotidianos como la gastronomía y la música, las diversiones como las jaranas, los carnavales, los toros y los gallos, entre otros.

Este esfuerzo multidisciplinario fue resaltado tempranamente por Angélica Palma quien afirmó "Como un Pancho Fierro que en lugar de colores a la aguada usara tinta y pluma, [Manuel] Segura nos relata los lances y el bullicio de las corridas de toros...concreta el encanto, hoy legendario de la saya y el manto...Ecos de la Lima del Ochocientos, de sentimientos y costumbres ya lejanos, que solo existen para la ciudad actual en libros viejos y láminas pretéritas" ${ }^{16}$. Segura defendió la cultura nacional frente a lo extranjero, como en estos versos:

He dicho que no iCamorra!

Porque quiero, aunque me encoheten,

Que mis hijos se desteten,

como yo, con mazamorra.

Y que como sus abuelos

15 Porras y Bayly $(1979,75)$ Las cursivas son mías para remarcar el fructífero diálogo cultural entre el escritor y el pintor. Esta carta confirma que ambos estaban involucrados en la construcción de un pasado colonial idealizado pero no puedo asegurar qué tan consciente era el esfuerzo. Agustín de la Rosa Toro escribió un interesante libro sobre las costumbres limeñas y Ricardo Palma inició el género de las tradiciones, breves relatos costumbristas.

16 Angélica Palma (1935: VIII-IX). 
Coman jalea y buñuelos

Y en vez de bisté, anticucho.

No me peta a mi querida

Quien diga a su hembra, madama,

Sino zambita, mi alma, mi vida. ${ }^{17}$

De manera más precisa, Raúl Porras sitúa a Fierro y sus contemporáneos bajo la influencia del Romanticismo y el Costumbrismo local: "Al afincar en la tierra y en el colorido local, el Romanticismo desemboca en el Criollismo, que es orgullo de lo propio, de la tradición regional, de los usos antiguos de la tierra y el rechazo de la intrusión inmigratoria y de los usos forasteros. De ellos deriva el nacionalismo estético implacable de nuestros costumbristas y su condenación de lo extranjero y aún de lo que no sea puramente limeño"18.

Por otro lado, también debemos romper la mirada local, Pancho Fierro formó parte del Costumbrismo, como bien apunta Natalia Majluf, esta corriente creó modelos de identidad, formatos que permitieron construir las diferencias nacionales a través de la serialidad y la comparación ${ }^{19}$.

Resulta también interesante observar que el Costumbrismo fue un vasto esfuerzo cultural que recorrió toda Hispanoamérica, comprometió a músicos, escritores, pintores, escultores, arquitectos, se trató del esfuerzo de intelectuales y personas no académicas que apuntaron en la misma dirección: guardar una memoria amable del pasado reciente y, al mismo tiempo, capturar el presente tan cambiante e inquietante. Creo que Pancho Fierro debe ser visto considerando todas estas complejas dimensiones ${ }^{20}$.

17 Manuel A. Segura "La moza mala"

18 Raúl Porras (1959: 22).

19 Natalia Majluf opina que Pancho Fierro no fue un pintor aislado ni un caso excepcional, otros pintores lo precedieron en la década de 1820, además, existía una tradición europea de pregoneros del comercio ambulatorio y el libro de trajes. Hay también paralelos en la obra de otros pintores costumbristas de otros países y el uso de estas imágenes como modelo para la fotografía. Natalia Majluf (2008: 25, 45).

20 Sobre los pintores latinoamericanos contemporáneos a Pancho Fierro ver el interesante estudio de Cisneros (1975: 42-80) y Natalia Majluf (2008).

\section{RAZA, FIESTA Y CUltura, Siglo XIX}

\section{Raza y cultura}

La sociedad colonial y republicana mantuvieron diversas categorías ordenadoras como la raza, la casta, el género, el honor, entre otros. Tanto en sus relaciones de sociabilidad como de conflicto, las personas se identificaban de manera individual y colectiva con alguna o varias categorías, exigían y guardaban el lugar que les correspondía.

Durante mucho tiempo hemos pensado que en la sociedad colonial y decimonónica la apariencia física y el color de la piel fue fundamental para ocupar un lugar en la sociedad, pero más que eso, era lo que la apariencia física podía representar en un contexto determinado donde también era importante "leer" signos exteriores como la ropa, la forma de hablar, las joyas y montura, también las relaciones sociales como quiénes eran los vecinos y el dueño de la casa donde vivían las personas, quiénes eran los parientes y amigos, padrinos y protectores, esto iba más allá y se consideraba el estatus legal, si la persona tenía obligaciones como pagar tributo o jornal, si estaba esclavizado, pertenecía a una cofradía, un gremio, una reducción, entre otros aspectos.

En ese sentido, Rachel O'Toole ha remarcado que los enfrentamientos entre individuos evidencian la forma en que las categorías culturales de la diferencia influenciaron y determinaron la sociedad. ${ }^{21}$ La etnicidad era importante, por supuesto, funcionaba plenamente para inferiorizar pero también valían otros indicadores como la ilegitimidad, la especialidad laboral, el estamento, por eso, las castas no deben ser entendidas exclusivamente como diferencias físicas o el simple color de piel.

Después de la guerra de Independencia se instaló la República liberal basada en el discurso de la igualdad y la libertad pero, en contraste, consolidó las diferenciaciones sociales, cultu-

21 Rachel O’Toole (2005: 50). Para Magnus Morner las jerarquías eran culturales y físicas formando una mezcla racial que reforzó la superioridad española y blanca (1980:18-19). 
rales y económicas, naturalizó la inferioridad del color oscuro de piel, de tal manera que las diferencias biológicas justificaron las diferencias socioeconómicas y la exclusión política de los sectores populares. El Liberalismo fue compatible con el racismo porque naturalizó la diferenciación, la elite peruana remarcó las tesis racistas en paralelo con la imposición de la cultura europea entendida como la modernidad, la civilización y el progreso, un escenario en el cual no encajaban los sectores populares.

Más allá de la etiqueta legal, las personas tenían una auto identificación étnica y las usaban de diferentes maneras, un tema que apenas empieza a ser entendido en el campo histórico peruano, por ejemplo Jesús Cosamalón acertadamente afirma que en la sociedad colonial el factor racial debe ser considerado como una definición legal más que biológica que ejerció de ese modo un papel importante en la construcción de las jerarquías sociales, pero que no consolidó el color de piel como el marcador definitivo, esto recién se hizo en el siglo XIX.22 Poco a poco, entre la década del 50 y la post guerra del Pacífico, la raza se convirtió en un fuerte factor diferenciador asociado a otros como la educación, saber leer y escribir, tener una profesión y un empleo "decente", frecuentar los lugares "correctos", comer y beber "decentemente", divertirse "civilizadamente", entre otros.

En ese sentido, las acuarelas de Pancho Fierro abren un camino inquietante para reflexionar sobre la cultura, entendida como un conjunto de símbolos, significados, representaciones y valores que los integrantes de la sociedad reconocen, usan y entienden en un tiempo específico. Debo confesar que soy consciente que estudiar la cultura desde la perspectiva de la historia implica riesgos, bordes imprecisos y caminos un tanto confusos por diversas razones, como las teóricas y las metodológicas, para nadie es un secreto que la historia no tiene tanta experiencia en estos terrenos como la antropología, sin embargo creo que vale la pena el esfuerzo.

Algunos historiadores han debatido con brillantez sobre los alcances y limitaciones de la

\footnotetext{
22 Jesús Cosamalón (2009: 29).
}

cultura y, en especial, de la denominada "cultura popular", las apreciaciones son variadas, como Mandrou que supone una pasividad absoluta y un sometimiento cultural en las clases populares, en dirección totalmente opuesta a la de Bajtin quien formuló la tesis de la influencia recíproca entre cultura popular y dominante, ambas paralelas y al mismo tiempo en contacto.

Por otro lado, Peter Burke ha insistido en la circularidad cultural, acertadamente sostiene que las clases populares y dominantes no se encuentran totalmente aisladas, al contrario, ambas consumen, adaptan, replantean y modifican elementos culturales que son transversales. En esa dirección, también me parece relevante las reflexiones de Carlo Ginzburg sobre cultura y mentalidad, en especial su enfoque sobre la connotación decididamente interclasista de las mentalidades colectivas, en el sentido de estudiar lo que hay en común entre todos los individuos de una sociedad ${ }^{23}$.

Por mi parte prefiero dejar de lado el término "cultura popular" para la sociedad colonial y decimonónica porque lo que distingo en las acuarelas, testimonios de viajeros, expedientes judiciales y otras fuentes históricas, es la unidad y circularidad cultural más que la diferencia, por lo menos entre el mundo colonial y el del siglo XIX.

En otras palabras, me parece que estamos ante un modo de vida compartido por las elites y los sectores populares, haciendo un esfuerzo de larga duración se descubren estructuras culturales similares desde la Colonia hasta el siglo XIX. En ese sentido, las acuarelas de Pancho Fierro coinciden con las críticas de los intelectuales y las observaciones de los viajeros, estos últimos extrañados por la cercanía y confianza entre la elite y los sectores populares, como Tadeo Haenke, un viajero francés que visitó Lima en el siglo XVIII, aunque sus opiniones deben ser leídas tomando en cuenta que poseía una ética del trabajo y ahorro diferente a la tradición hispanoamericana:

"Se ofrece sin duda a primera vista la idea de que un país tan falto de medios de subsisten-

23 Un interesante debate sobre cultura y mentalidades en Carlo Ginzburg (2000: 9-24). 
cias, los jornales deben ser por consiguiente baratos y se encontrarán muchos operarios, pero por lo contrario, en ninguna parte son respectivamente más caros y los edificios salen costosísimos por la exorbitante mano de obra. Un palafranero gana diariamente 8 reales de aquella moneda, el oficial doce y a proporción todos los demás habiendo también peones de 6,7 y 8 reales. Con todo no pueden mantenerse y andan siempre andrajosos, prueba cierta de que trabajan poco. Así me lo aseguraron en Lima diciéndome que se ocupan solo dos días a la semana en trabajar y que los restantes los emplean en jugar o enamorar. Se dan los trabajadores una vida miserable gastando apenas un real diario en la comida y la cena." ${ }^{24}$

Las cursivas resaltan los estereotipos presentes en Haenke que relacionaba a los sectores populares con la suciedad, la vagancia y la violencia pero una nueva lectura de este párrafo sugiere que los limeños tenían otra ética del trabajo y del ocio. Según Haenke algunas personas administraban sus ingresos de tal forma que priorizaban ciertas actividades sociales como paseos, cortejos, diversiones, beber licores, en detrimento de otros gastos cotidianos. También Terralla y Landa los retrató con su viperino estilo:

"Mucha gente a caballo miras entrando y saliendo. Fingiendo mucho negocio el que es un ocio perpetuo. Que ves a muchas mulatas destinadas al comercio, las unas al de la carne las otras de lo mesmo... Verás zánganos sin fin y los más de ellos drogueros, sin oficio ni destino y sin más vida que el juego. Mesas de billar y trucos las verás amigo a cientos donde van muchos ociosos a perder la plata y el tiempo. Verás en las mismas casas de diversiones otros juegos, mas otros no los verás por ser de ocultos encierros. Verás muy adelantado la ciencia y el arte del juego en que más de dos mil hombres están cursando a lo menos" ${ }^{25}$.

Una gran mayoría de los limeños trabajaba a jornal y eso significaba permanecer en la calle buscando el jornal diario, esperar, caminar de un lado para otro, pasar el rato, conversar con los

24 Tadeo Haenke (1909: 28).

25 Terralla y Landa (1854: 125). amigos, visitar a los parientes, jugar a los naipes y dados, ir a las peleas de gallos, etc. De allí la reiterada acusación de vagancia en Terralla y Landa. En ese sentido, los limeños desarrollaron una cultura que incidía más en la vida cotidiana inmediata dando mucha importancia a los aspectos festivos.

Un siglo después los testimonios son reiterativos, remiten a una realidad semejante a la del siglo XVIII, Lima parece ser el paraíso del relajo social, la vagancia y la diversión general. Esto fue resaltado por Fanni Muñoz en su estudio sobre las diversiones públicas en Lima, cita a Gabriel Lafond por ejemplo, quien señaló que los limeños eran dados a las costumbres fáciles y disolutas y Botmiliau notó que no había gran diferencia entre el Perú de los virreyes y el republicano ${ }^{26}$.

Hasta el mismo Ricardo Palma, tan perspicaz, notó las continuidades culturales entre la Colonia y la República. En El baile de la Victoria exclama:

No con el último disparo del fusil en Ayacucho desapareció la vida colonial. En punto a costumbres, se siguió en toda casa de buen gobierno almorzando de nueve a diez de la mañana, comiendo de tres a cuatro de la tarde, cenando a las diez de la noche, rezando el rosario en familia...el mobiliario de las casas, la indumentaria personal, las fiestas y las procesiones religiosas, los capítulos para la elección del prior o de la abadesa, capítulos en los que todo el vecindario se inmiscuía con un calor nada parecido al de los ciudadanos en las recientes elecciones de parroquia, las corridas de toros, el reñidero de gallos y las funciones teatrales, los saraos de buen tono, los holgorios populacheros, todo, todo subsistía sin ápice de discrepancia como en los días de la colonia. Nada había cambiado ${ }^{27}$.

Para el siglo XIX y la creación de la República, Jesús Cosamalón sostiene que el cuadro se volvió más complejo por cuanto "el racismo y la discriminación no fueron incompatibles con la

26 Un buen análisis de las percepciones de los viajeros en Fanni Muñoz (2001: 35-42).

27 Ricardo Palma (1953: 1124-1125) Citado por Fanni Muñoz (2001: 37-38). 
república igualitaria porque el sistema permitía escapar a las etiquetas raciales por medio de la movilidad social, provocando un proceso dual y no contradictorio: rigidez en las denominaciones raciales y movilidad social a partir de los factores de clase, que permitían, al mismo tiempo, el escape de esas etiquetas raciales. Esto significa que, a diferencia de la sociedad colonial, en la época republicana la relación entre las variables tales como educación, riqueza o estilo de vida coincidieron de manera más estrecha con los colores de piel"28.

En esa dirección, las acuarelas de Pancho Fierro evidencian que hasta bien entrado el siglo XIX Lima era una ciudad sin fronteras culturales. Quiero remarcar algunas acuarelas como La almuercera, fechada en 1820, representa una afro descendiente con vestido verde de escote profundo, sobre su cabeza carga una olla muy grande y, a su espalda, asoma el rostro de un niño envuelto en una manta, al estilo indígena.

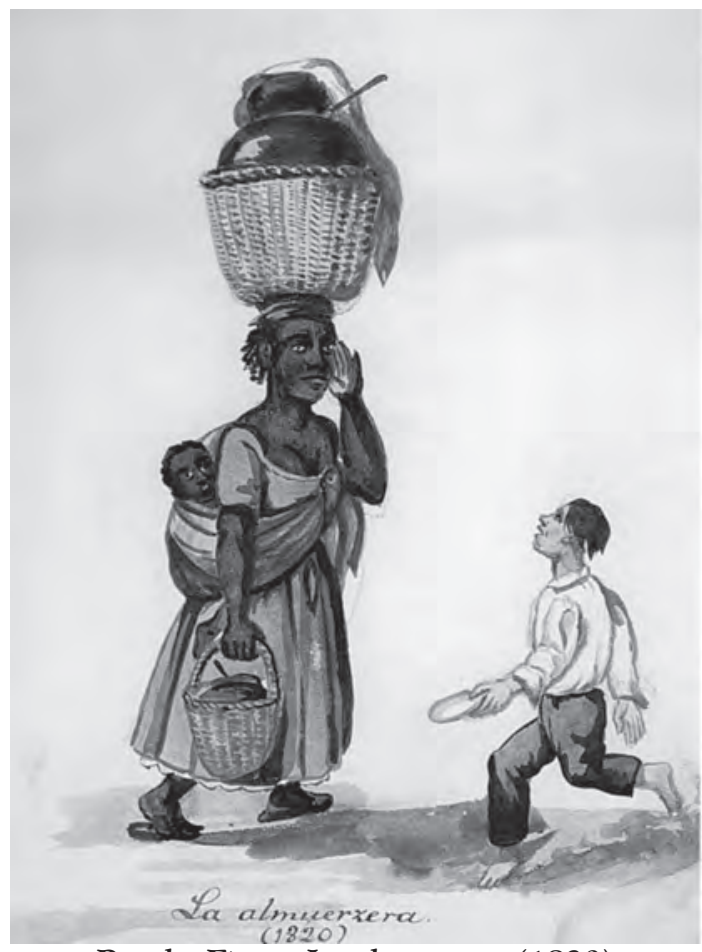

Pancho Fierro, La almuercera (1820) Municipalidad de Lima.

28 Jesús Cosamalón (2010: 7).
En Un cuarto de callejón, una mujer de origen afro es representada de espaldas cogiendo cuyes, un alimento considerado tradicionalmente indígena ${ }^{29}$. Asimismo, algunas acuarelas representan a tapadas vistiéndose y desvistiéndose, llama la atención que usan trenzas como parte del peinado cotidiano.

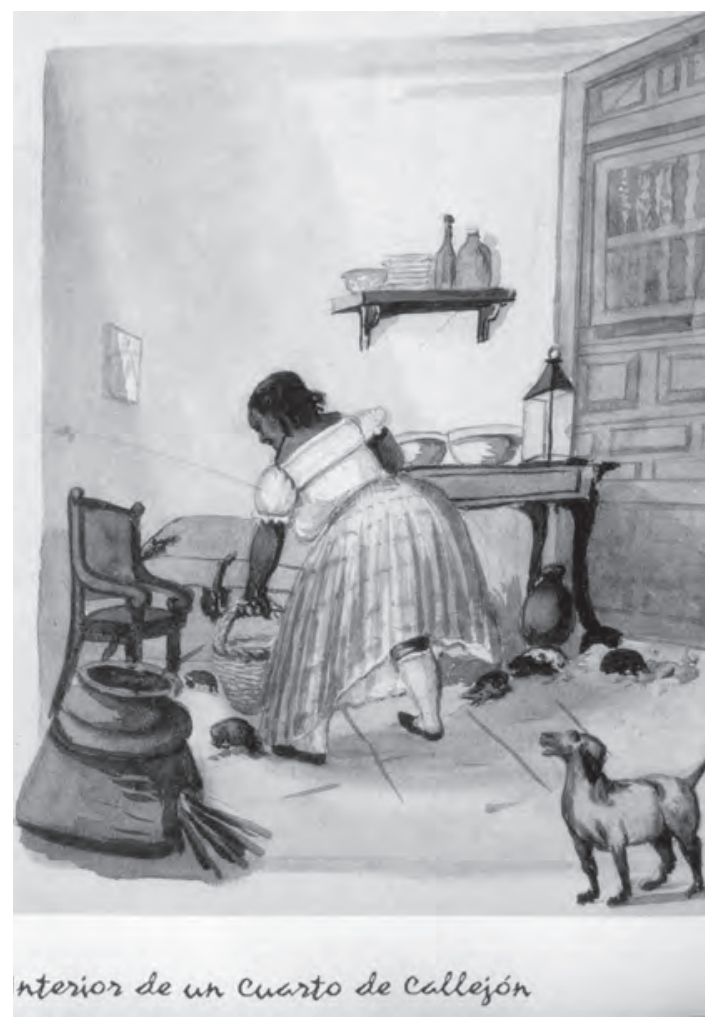

Pancho Fierro, Interior de un cuarto de callejón. Reproducido en Cisneros Sánchez, Manuel, Pancho Fierro y la Lima del 800. Lima, Importadora, Exportadora y Librería García Ribeyro SCRL, 1975.

Las acuarelas que representan escenas de bailes nos llevan a cuestionar la clásica diferenciación entre bailes populares y aristocráticos. Algunos bailes fueron considerados "de salón" es decir elegantes, como el minué y el ondú -más antiguos por ser de principios del siglo XIX-y otros bailes muy estimados como el fandango, la mariquita, el guachambe, la cachucha, el valse y la polka. Pero el baile más entusiasta

29 Agradezco a Jesús Cosamalón la referencia sobre esta acuarela. 


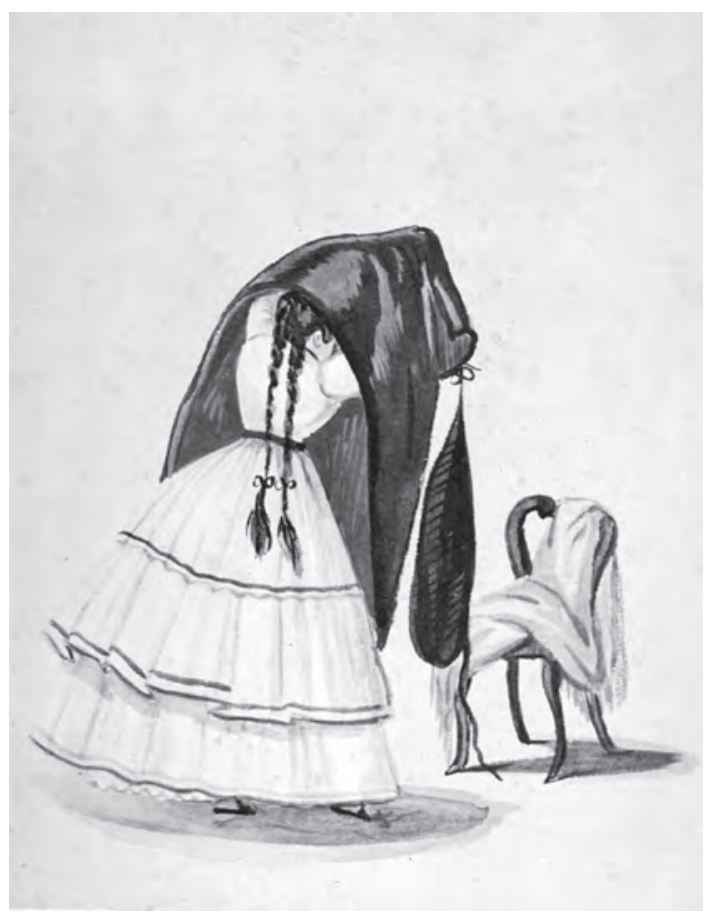

Pancho Fierro, Tapada desvistiéndose. Reproducido en Cisneros Sánchez, Manuel, Pancho Fierro y la Lima del 800. Lima, Importadora, Exportadora y Librería García Ribeyro SCRL, 1975.

fue, sin duda alguna, la zamacueca llamada también maicito, mozamala, zanguaraña, sajuriana y chilena, porque fue llevada hasta el sureño país hacia 1830, pero durante la Guerra con Chile fue rebautizada por Abelardo Gamarra como "marinera" en homenaje al comandante Miguel Grau y los héroes del Huáscar ${ }^{30}$.

En los tiempos de Pancho Fierro y Ricardo Palma se distinguían dos tipos de zamacueca, la "decente" o estilo salón, que se ejecutaba con piano, guitarra y cajón, más lenta, al estilo de la marinera limeña actual y la zamacueca "borrascosa" más movida, las acuarelas muestran cuerpos contorsionándose al compás de la música, los rostros son más expresivos, las sonrisas afloran, los gestos son más coquetos. Este último baile era el preferido de los habitantes limeños, aristócratas y plebeyos y, tal vez, también lo haya sido para el pintor y sus clientes pues se repite constantemente en las acuarelas pan-

30 Ricardo Cantuarias (1995: 65-70). chofierristas. A pesar de la distinción "de salón" y "borrascosa" las acuarelas muestran a las personas disfrutando de este baile, sin distinción socioeconómica o étnica ${ }^{31}$.

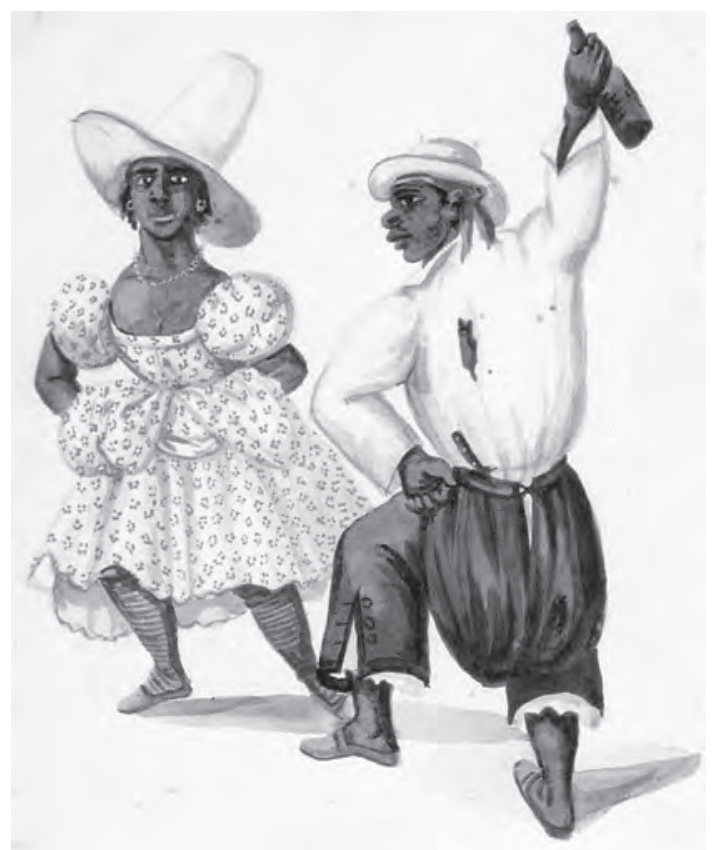

Pancho Fierro, Zamacueca borrascosa, reproducido en Majluf, Natalia y Marcus B. Burke, Tipos del Perú. La Lima criolla de Pancho Fierro. Madrid, Ediciones El Viso, 2008.

Las acuarelas representan diferentes tipos populares, en el primer caso, la zamacueca borrascosa representa una pareja en pleno movimiento, ella con vestido coqueto, amplio escote y senos bien marcados, levanta la falda para mostrar sus medias, y de paso, las piernas bien

31 Para Ricardo Cantuarias, la zamacueca era considerada un baile indecente y no se ejecutaba en las casonas de la elite (1995: 65) Sin embargo, Pancho Fierro demuestra que todos se entusiasmaban por este baile. En esa época ya existían críticas contra los bailes, por ejemplo, Pardo y Aliaga en Frutos de la educación, plantea el tema de la joven y delicada protagonista que pierde una oferta de matrimonio después de bailar la zamacueca que es tildada de indecente: "No, no hay decencia que valga, porque con decencia no hay zamacueca bien bailada" Pardo y Aliaga (1869: 191) Después de la guerra con Chile y durante la República Aristocrática las criticas se hicieron más fuertes, ver Fanni Muñoz (2001). 

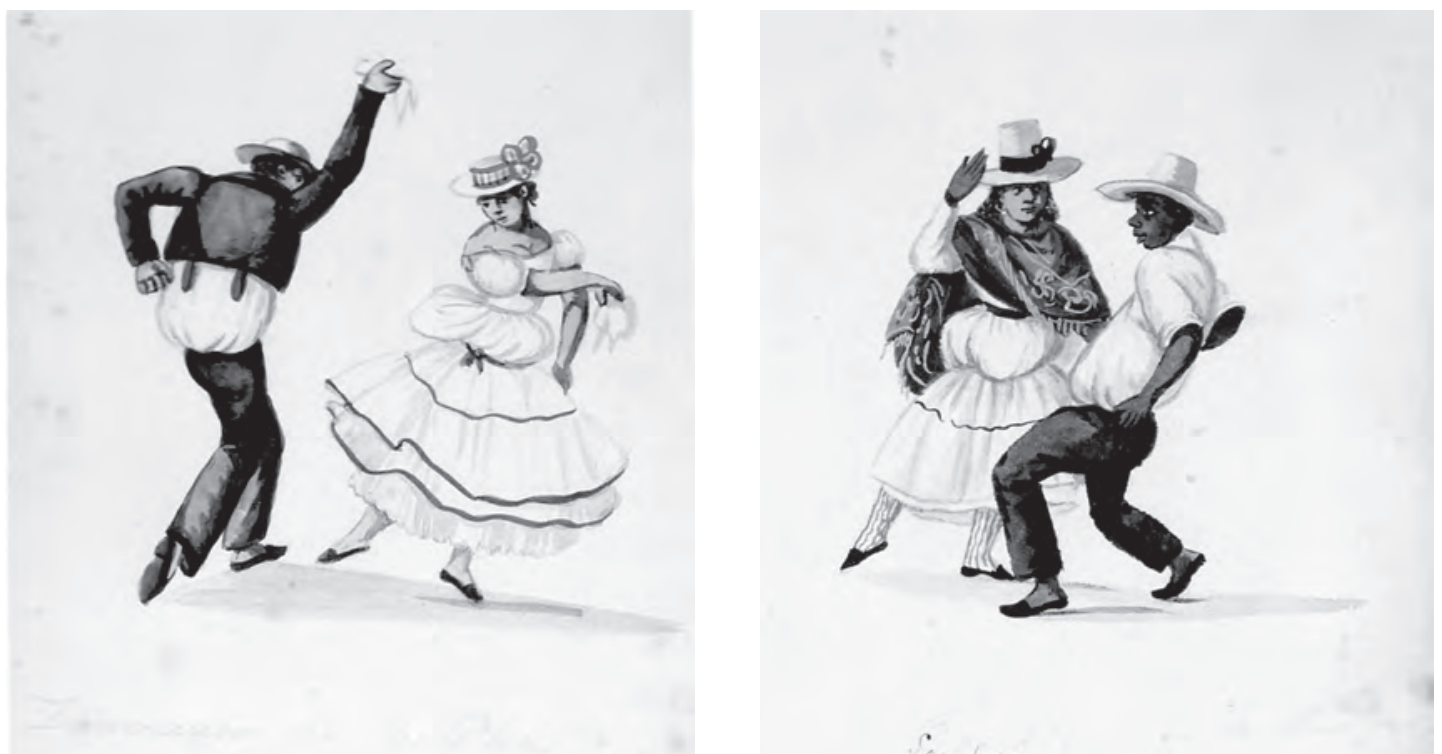

Pancho Fierro, Zamacueca, reproducido en Majluf, Natalia y Marcus B. Burke, Tipos del Perú. La Lima criolla de Pancho Fierro. Madrid, Ediciones El Viso, 2008.

torneadas. En contraste, sus aretes y collar de oro brillan. Esta acuarela enfatiza en tres elementos centrales: pobreza, violencia y alcohol. El hombre está armado, de su cintura asoma el mango de un arma blanca, su camisa tiene un agujero, parece vieja, además sostiene una botella mientras baila.

Coincidiendo con Pancho Fierro, Ricardo Palma afirma que la zamacueca era bailada abiertamente por los sectores populares y, de manera más discreta, por las elites limeñas. En la tradición "El mes de diciembre en la antigua Lima" Palma refiere que las familias armaban un altar llamada de la Purísima porque estaba dedicada a la virgen, frente a la cual los invitados rezaban el rosario, cantaban villancicos y después, hacia las diez de la noche, empezaba la jarana:

"Jarana en regla. Las parejas se sucedían bailando delante del altar el ondú, el paspié, la pieza inglesa y demás bailes de sociedad por entonces de moda. Por supuesto que las copas menudeaban, y ya después de media noche se trataba a la Purísima con toda confianza, pues dejándose de bailar sosos y ceremoniosos, entraba la voluptuosa zamacueca con mucho de arpa y cajón"32.

Esta acuarela equivale a la tradición de Palma, ambas son sincrónicas. Representa el espacio profano y sagrado juntos, confundidos en uno solo, no son contradictorios, son más bien complementarios. En el primer plano se representa lo profano, el arpista, la pareja bailando, él inclinado hacia la mujer, agitando un pañuelo rojo mientras ella, con vestido amarillo, con escote sencillo y brazos descubiertos, levanta la falta discretamente para dejar ver su pequeño pie calzado y cubierto con media blanca. Al fondo, y en un plano secundario está el espacio sagrado donde se emplaza el altar de la Purísima.

También en el Son de los Diablos, alegre comparsa de negros que danzaban disfrazados con máscaras acompañados de una banda de música, entre los instrumentos musicales figuran la cajita y la quijada de burro, consideradas tradicionalmente inventadas y usadas por negros, pero también aparece el arpa, instrumento usado en la música andina. También se observa un hombre blanco tocando la quijada de burro.

\footnotetext{
32 Ricardo Palma (1921: 119).
} 


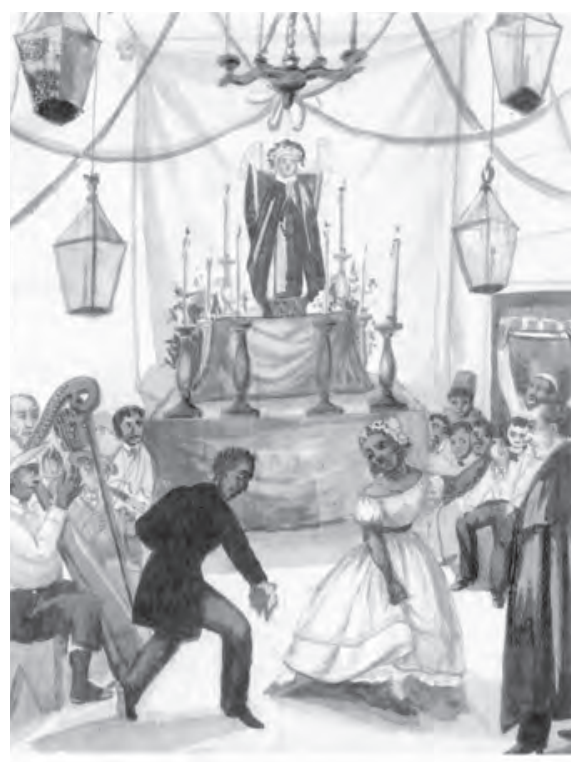

Altar de la Purisima

Pancho Fierro, Altar de la Purísima. Tomado de Cisneros Sánchez, Manuel, Pancho Fierro y la Lima del 800. Lima, Importadora, Exportadora y Librería García Ribeyro SCRL, 1975.

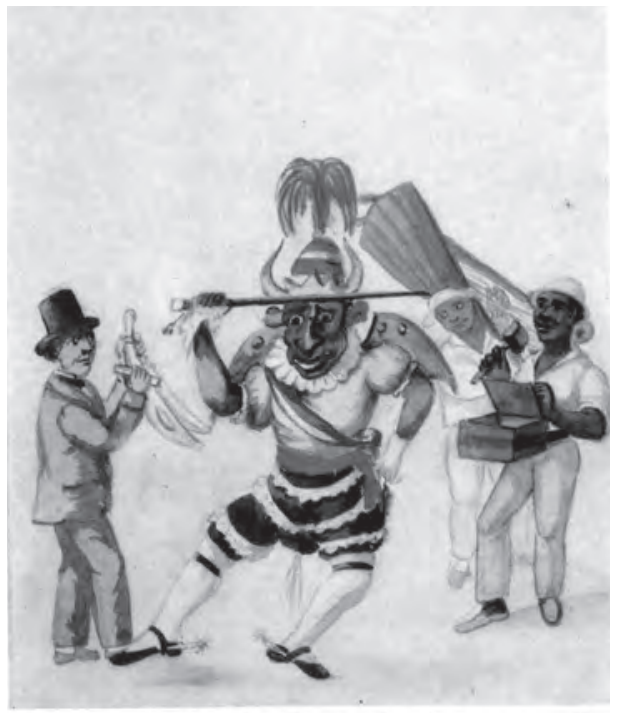

3/ Son de los Diablos, Procesión de cuasimodo

Pancho Fierro, 3/Son de los Diablos. Procesión de Cuasimodo. Tomado de Cisneros Sánchez, Manuel, Pancho Fierro y la Lima del 800. Lima, Importadora, Exportadora y Librería García Ribeyro SCRL, 1975.
Las relaciones interétnicas y culturales aparecen continuamente en las acuarelas, por ejemplo, en Zamacueca al estilo salón hay un pianista negro mientras una pareja baila alegremente. En Entierro de una criatura aparecen muchos personajes indígenas, una pareja baila la zamacueca mientras un negro vestido con poncho, prenda de vestir indígena, baila y sostiene una botella. En otra acuarela sin título nuevamente vemos a un negro vestido con poncho. Por último, en la acuarela que representa la Procesión de santa Rosa de Lima, se observan muchos indígenas, pero también se distingue un negro, vestido con poncho, bailando alegremente con una india o mestiza, de espaldas.

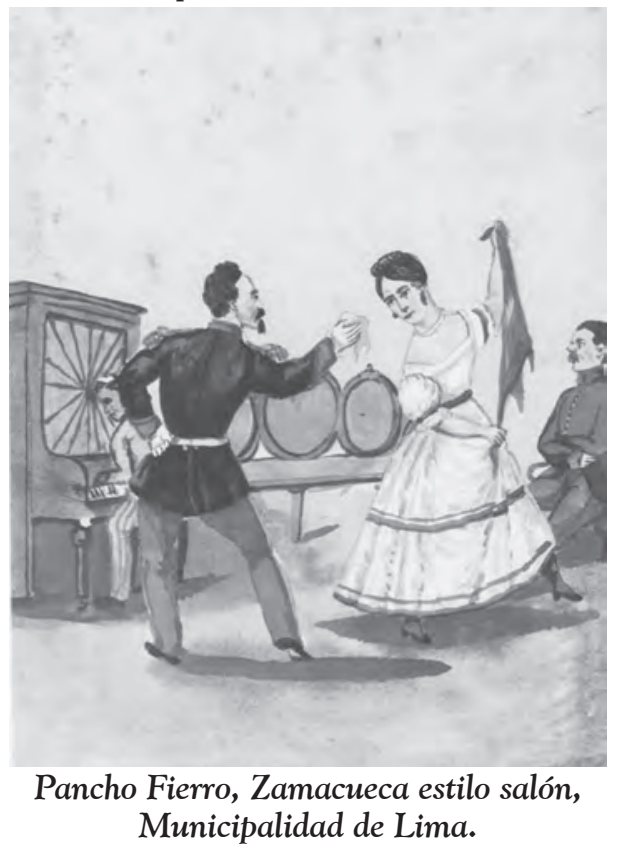

La primera acuarela nos remite a un espacio intercultural donde el afro descendiente participa de manera marginal, toca pero no baila, es decir, es sujeto pero no participante. En contraste, la segunda acuarela muestra al afro descendiente bailando alegremente con su pareja. Si observamos detenidamente, el hombre lleva poncho, tiene una botella de licor en una mano y está atento a los movimientos de su pareja que es una mujer andina.

Como se ha podido apreciar en las acuarelas, hombres y mujeres, aristócratas y plebeyos, 


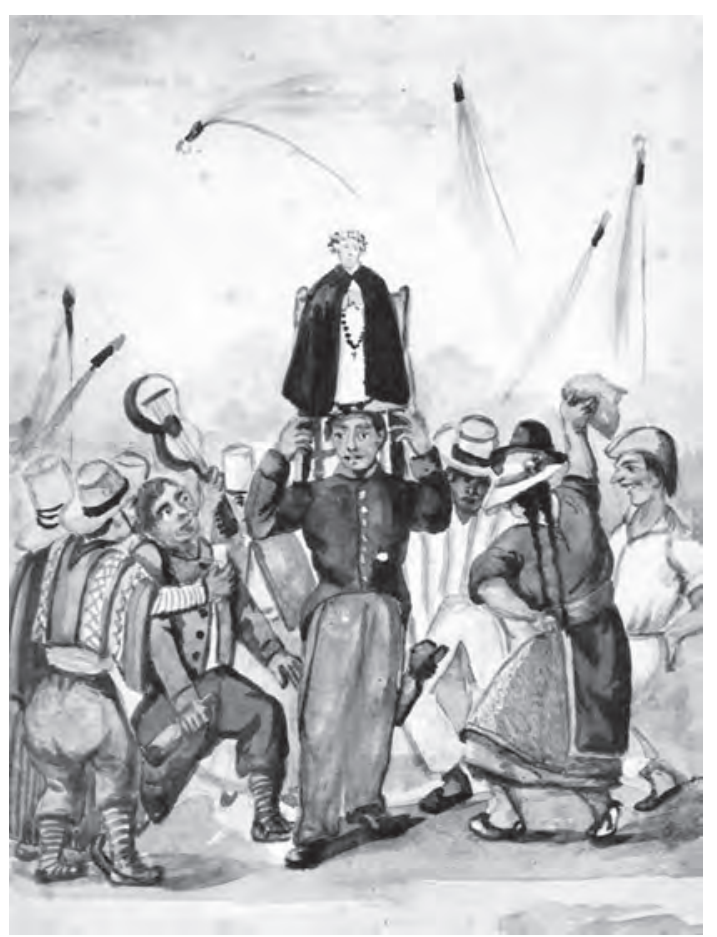

Fierro, Procesión de Santa Rosa. Tomado de Cisneros Sánchez, Manuel, Pancho Fierro y la Lima del 800. Lima, Importadora, Exportadora y Librería García Ribeyro SCRL, 1975.

blancos, indios y negros, libres y esclavos, todos y todas, participaban de una cultura común, bailes, música, comida, licores, pelea de gallos, corrida de toros, paseos en la Alameda y Amancaes, entre otros aspectos. $\mathrm{Al}$ ser una ciudad pre moderna no existían elementos culturales ni espacios exclusivos para determinados grupos étnicos o socioeconómicos.

$\mathrm{El}$ inicio de la diferencia tiene que ver con otros contextos, para mí tendría que fecharse, con mayor nitidez, entre el apogeo del guano y la post guerra con Chile por cuanto en esa coyuntura surgió un grupo con proyección económica, social y política ${ }^{33}$. Ahora bien, el

33 Sobre la Plutocracia/Burguesía y Oligarquía hay un apasionado debate en el Perú, ver por ejemplo las opiniones contrapuestas de Bonilla $(1974,1980)$ y Carmen Mc Evoy $(1994,1997)$. Por otro lado, la discusión se ha enriquecido con Ulrich Mücke (2010) quién otorga una mirada renovadora al analizar la burguesía peruana desde su experiencia social a través del Partido Civil. proceso de surgimiento, maduración y consolidación de esta elite es bastante complejo, escapa de estas páginas, pero me parece relevante situar a la Plutocracia y luego a la Oligarquía en un contexto cultural, ambos grupos fueron grandes consumidores de la cultura europea, entendieron la modernidad bajo los patrones occidentales y rechazaron abiertamente la cultura local.

En diferentes momentos, pero con las mismas intenciones "modernizadoras", esta elite impulsó la construcción de nuevas edificaciones al estilo francés, intervinieron la ciudad, modificaron los espacios públicos, implantaron las óperas, dramas y ballet, incentivaron el consumo de licores importados y comida francesa, tildando todo lo peruano de inferior, salvaje y atrasado ${ }^{34}$.

Pancho Fierro llegó a ver algunos de estos cambios, estoy segura que los notó, de allí que se aferró al pasado al igual que sus clientes y amigos, ellos también querían perennizar una Lima que se estaba transformando.

\section{Cuerpos, fiesta y cultura "a la limeña"}

Las acuarelas de Pancho Fierro hacen posible marcar reflexiones entre cultura, fiesta y ethos limeño. Diversos viajeros entre los siglos XVIII y XIX describieron Lima como una ciudad festiva, relajada y sensual. Entre los numerosos testimonios me gustaría resaltar dos en particular, primero los comentarios de Juan Jacobo Von Tschudi quien visitó Lima entre 1838 y 1842, entre sus agudas observaciones anotó que:

Las procesiones son el pasatiempo favorito de los habitantes de Lima y son muy concurridas, se puede afirmar que es raro que los limeños se

34 La historia cultural en el Perú no tiene mucho tiempo y se relaciona más con la medicina, la higiene, la salubridad, la muerte, la fiesta, el cuerpo y las costumbres. Ver por ejemplo Jesús Cosamalón (1993), Fanni Muñoz (2001) Juan Carlos Estenssoro (1996, 1997), Rolando Rojas (2005), Francesca Denegri (1996), Rosa M. Acosta (1997), Marcos Cueto (1997), Gerardo Álvarez (2001), Peter Elmore (1993), Natalia Majluf (1994), María Emma Mannarelli (1999), Gabriel Ramón (1999), Panfichi y Portocarrero (1995), Jorge Lossio (2003) 
diviertan tanto en una fiesta mundana como en estos actos religiosos. La mayoría de las mujeres asisten a la procesión como tapadas, se dedican a la coquetería y piensan en cualquier cosa menos en la religión ${ }^{35}$.

Por su parte, Victorino Lastarria visitó Lima en 1851 y expresó que las calles eran bulliciosas, llenas de gente: "Lima es uno de los pueblos sin ocupaciones y callejero, sin felicidad material pero alegre y bullicioso... hay siempre una concurrencia numerosa que se mueve y charla. Sobre todo en las fiestas públicas...la gente se pasea, va a misa y por la tarde en la plaza..."36.

Ambos tipificaron a los limeños como festivos y relajados pero también hay otro aspecto que me gustaría remarcar, la relación entre fiesta y piedad religiosa "a la limeña" aunque más bien es típica de una sociedad pre moderna. Lastarria enfatizó en el circuito iglesia-plaza-mercado-calle, en otras palabras nos estaba hablando de los espacios públicos como ejes de la vida cotidiana, una "sociedad abierta" 37 que podía mostrar, sin embarazo alguno, una piedad religiosa en un marco festivo.

De manera más directa, Tschudi afirmó que los limeños eran capaces de divertirse en una procesión tanto como en una fiesta mundana, dicho así podría parecer extraño porque no hay separación entre lo profano y lo sagrado, pero la religión en el Perú colonial, republicano y actual sigue siendo un espectáculo público cuyas raíces se pueden entender en el marco de una Iglesia Católica atacada por el protestantismo europeo y tambaleante por el poco éxito de las extirpaciones de idolatrías, en ese contexto la Iglesia impuso la piedad barroca como espectáculo, la

35 Juan Jacobo Tschudi (1966: 129) Las cursivas son mías para enfatizar en la crítica masculina contra las mujeres, de manera sesgada silencia la actitud de los hombres, consideradas más correctas aunque todos y todas disfrutaban igual de la fiesta.

36 Victorino Lastarria (1851: 41)

37 Tomo el término "sociedad abierta" en el mismo sentido que aduce María Emma Mannarelli para la "casa abierta" como un espacio doméstico pre industrial donde los individuos orientan sus vínculos personales de manera pública a diferencia de la sociedad burguesa que "cierra" y ordena la casa bajo los conceptos de hogar e intimidad (2004) fe y el recogimiento fueron vinculados con la diversión.

En la sociedad colonial y republicana la religiosidad fue una actividad más allá del misticismo y la espiritualidad, también fue un conjunto de sentimientos internos y prácticas externas importantes para reforzar vínculos horizontales y verticales, étnicos y estamentales, sexuales y afectivos. En las ciudades coloniales, y luego las republicanas, a cada paso había una iglesia, un convento, un monasterio, en sus calles era común ver beatas, curas, confesores y doctrineros, las campanadas marcaban los ritmos cotidianos de las haciendas, obrajes, talleres y hogares. Las iglesias eran centros de reunión de hombres y mujeres, centros de lucimiento banal, religiosidad y recogimiento, espacios para milagros y prodigios, rumores y conspiraciones.

La sociedad peruana, primero colonial y luego republicana, fue pródiga en procesiones y fiestas religiosas, como la procesión del Corpus Christi, la Virgen del Carmen, la Inmaculada Concepción, la Navidad, la Semana Santa, etc. El estilo Barrroco pretendió mostrar la fe públicamente, las fachadas fueron más ostentosas, la fe se manifestó en el espacio público, como las procesiones y fiestas religiosas, los autos de fe y los autos sacramentales. En todas estas fiestas los esclavos y libertos desfilaban bailando y tocando sus instrumentos musicales, algunos disfrazados de fieras salvajes de tal manera que se enfatizaba en su supuesta inferioridad étnica. Pero, a pesar de todo, las comparsas de negros, con su música y baile, constituían el cierre de fiesta, contagiaban alegría a todos los participantes.

Se podría afirmar que sin ellos no había fiesta. Roberto Rivas estudió la participación de los negros limeños en el Corpus Christi, una de las procesiones más importantes del calendario católico, duraba ocho días y paralizaba toda la ciudad. Los negros participaron como actores principales en la Octava y en la Infraoctava, es decir en las fechas centrales. El domingo de la Infraoctava era muy importante, las cofradías de negros abrían la procesión al salir del Convento de santo Domingo, luego desfilaban los domini- 
cos y, como apoteósico final, aparecía el Santísimo Sacramento ${ }^{38}$.

La presencia de las cofradías de negros fue más complejo de lo que comúnmente pensamos y merece más atención. Para empezar desfilaban divididas en naciones africanas, cada una con su rey y reina, súbditos y criados, todos llevaban ropas y joyas lujosas como describen Tadeo Haenke, el articulista de El Mercurio Peruano y la Gaceta de Lima 39 . Detrás iban los "diablillos", negros disfrazados de osos, leones, serpientes, algunos con la cara teñida, otros con plumas y pieles de animales, todos con instrumentos musicales, bailando. Cerraban el desfile las "invenciones" o máscaras: los gigantes, cabezudos o papahuevos que eran figuras deformes con licencia para hacer bromas al público. Más allá de las descripciones y el orden de los desfiles, me parece de suma importancia reflexionar en torno a las identidades, símbolos y representaciones que se daban en este espectáculo.

Todos estos elementos indican una cultura de fiesta donde se mezclaban elementos culturales andinos, españoles, africanos y hasta árabes. La calle fue el gran escenario para símbolos dispares como diablos y ángeles, moros y cristianos, enanos, papahuevos y gigantes, salvajes y caballeros. Como bien afirma Estenssoro, esta fiesta sincrética fue buscada y alentada por los mismos españoles con el fin de lograr que se disolviesen las diferencias locales. Es pues una transacción cultural en busca de una cultura homogénea ${ }^{40}$.

La sociedad colonial presentaba rasgos estamentales, cada grupo con sus elementos de identidad, sus códigos simbólicos, sus espacios, derechos y deberes, autonomías y subordinaciones. Al mismo tiempo, estas entidades culturales, étnicas y estamentales formaban parte de un solo cuerpo, integrados bajo la corona. La fiesta, entendida como un espacio temporal de diversión, sirvió para construir esta armazón social fragmentada y unida al mismo tiempo.

38 Roberto Rivas (2003, tomo I, pp.35-63)

39 El Mercurio Peruano, 16 de junio de 1791, Tadeo Haenke (1901: 40-43) La Gaceta de Lima, 20 de junio de 1756.

40 Juan Carlos Estenssoro (1997: 182)
Sin embargo, en el siglo XVIII las cofradías fueron criticadas por algunos como Carrió de la Vandera: "Su canto es un aúllo...De ver sólo los instrumentos de su música se inferirá lo desagradable de su sonido. La quijada de un asno, bien descarnada, con su dentadura floja, son las curdas de su principal instrumento que rascan con el hueso de carnero, asta u otro palo duro... en lugar del agradable tamborilillo de los indios, usan los negros un tronco hueco y a los dos extremos le ciñen un pellejo tosco...sus danzas se reducen a menear la barriga y las caderas con mucha deshonestidad a que acompañan con gestos ridículos" ${ }^{41}$.

Estas palabras tan duras siguen la lógica del siglo XVIII y las Reformas Borbónicas que pretendían construir una sociedad unida bajo un solo cuerpo sin tantas ambigüedades y fronteras difusas, todos sujetos a una autoridad central, fuerte, rígida.

En adelante, los reformadores atacaron las fiestas profanas, la sensualidad de los bailes, la alegría desbordante, el inquietante contacto entre hombres y mujeres, la música cadenciosa, el lujo en los vestidos, los altares, las fachadas, todo. Siguiendo esos afanes controlistas, el nuevo estilo arquitectónico denominado Neoclásico desplazó al Barroco, las iglesias se tornaron más severas, de líneas rectas, sin curvas ni ondulaciones sensuales, con escasa ornamentaciones. En esa nueva tendencia, la cultura festiva de los negros fue atacada reiteradas veces, como en $\mathrm{La}$ Gaceta de Lima:

"En lo extensivo de esta procesión -el Corpus Christi- la numerosa ocurrencia de negros bozales, que a ellas asisten por parcialidades de naciones y cofradías, con separación de sexos, en que salen los varones con las invenciones más ridículas, exercitando movimientos y suertes de gran ligereza, con escudos, armas, banderas e insignias de sus aderezos de sus países, las mujeres con el lucimiento de las más costosas estofas, aderezos de oro, plata y piedras, simbolizando, con copioso séquito, las princesas de sus nativos territorios y dando el lleno de la diversión la variedad de ideas, que

41 Carrió de la Vandera (1942: 325-327) 
con diestros saltos componen sus marchas, al compás de los bien aunque incultos parches pulsados conciertos de sonajas y extravagantes alboxes" ${ }^{\prime 2}$.

Como certeramente afirma Estenssoro, la guerra contra la fiesta había empezado ${ }^{43}$. También deberíamos agregar que era una guerra contra la sensualidad, el relajo y el espíritu festivo que caracterizó a la misma ciudad durante tres siglos.

Durante el siglo XIX las críticas modernizadoras continuaron cada vez más fuertes ${ }^{44}$. Sin embargo, los sectores populares defendieron sus reuniones religiosas festivas, en el caso de los negros dejaron de ser los protagonistas visibles de la fiesta, pero se atrincheraron en espacios más pequeños y este proceso fue más acelerado en la República donde las elites modernizadoras, ya diferenciadas de los sectores populares y con una clara influencia cultural europea, pretendían barrer con los entretenimientos ahora considerados populares y, por lo tanto, salvajes.

Sin embargo, en cada callejón, barrio o galpón de negros, indios y otras castas se construía una pequeña capilla dedicada a una cruz, una virgen o un santo para la protección local. Los vecinos organizaban misas y rezos alrededor de la imagen. También celebraban una fecha central, el día de la cruz, virgen o santo. La fecha central incluía la procesión, la misa en la iglesia, una comida, si había más dinero podía darse un espectáculo de fuegos artificiales, por supuesto siempre se ofrecía licor y baile general. Estas fiestas eran espacios de socialización entre los sectores populares, ayudaban a reforzar la fe cristiana y reforzaban los vínculos étnicos barriales solidarios.

Este aspecto central del ethos limeño fue captado brillantemente por Pancho Fierro, por

42 La Gaceta de Lima, 20 de junio de 1756.

43 Juan Carlos Estenssoro (1997: 192)

44 Fanni Muñoz (2001) Este apasionante trabajo analiza los afanes modernizadores de una elite peruana europeizada que rechazó la comida, las bebidas y diversiones de vieja tradición colonial. Para las diversiones públicas de los afroperuanos a inicios del siglo XX ver el trabajo pionero de Susan Stockes (1987) y el de Aldo Panfichi (2000). ejemplo en la "Procesión del Jueves Santo" se percibe claramente estas características, la piedad religiosa entretejida con otros elementos culturales como el clima alegre, cohetecillos, comida, licores, mujeres sonrientes y sensuales, el coqueteo masculino, entre otros aspectos.

Este punto trae a colación otro, el cuerpo como entrada teórica en tanto permite cruzar otros hilos que articulan las sociedades como la raza, el honor y el género, entre otros. Norbert Elías marcó una ruta atractiva para los estudios culturales cuando investigó el comportamiento corporal en la sociedad observando que algunos rasgos que nosotros consideramos "educados" en realidad fueron aprendidos, impuestos por la sociedad occidental moderna en un lento proceso civilizatorio. Así, el cuerpo es intervenido por diversos agentes que ejercen un poder externo, político y social, obligando a asumir determinadas actitudes y/o replantear los usos y comportamientos en sociedad ${ }^{45}$.

En ese sentido, coincido plenamente con Kogan cuando afirma que los cuerpos son transmisores de significados sociales y, en especial, de las prácticas alimenticias, cargadas de sentidos de procesos sociales ${ }^{46}$. Como bien afirma María Emma Mannarelli, el cuerpo ofrece referencias centrales para la experiencia vital de las mujeres en términos de sus funciones propiamente físicas (menstruación, parto, lactancia, maternidad) ${ }^{47}$ pero, más allá de sus límites físicos, el cuerpo también se convierte en objeto de redefiniciones de los discursos, se convierte en campo de negociaciones, representaciones, orden y desorden, imposiciones y liberaciones que pueden ser leídos, aprehendidos y entendidos aplicando una lectura hermenéutica a los textos escritos e visuales.

La sociedad limeña tenía formas de percibir el cuerpo femenino en concordancia con

45 Norbert Elías (1989: 96) Sobre el cuerpo como construcción cultural ver Sennet (1994) y Laqueur (1994)

46 Liuba Kogan (2003: 9).

47 María Emma Mannarelli ofrece una brillante reflexión histórica sobre el cuerpo y agradezco mucho sus clases y amistad que motivaron parte de este estudio. Mannarelli (1999: 20-28). 

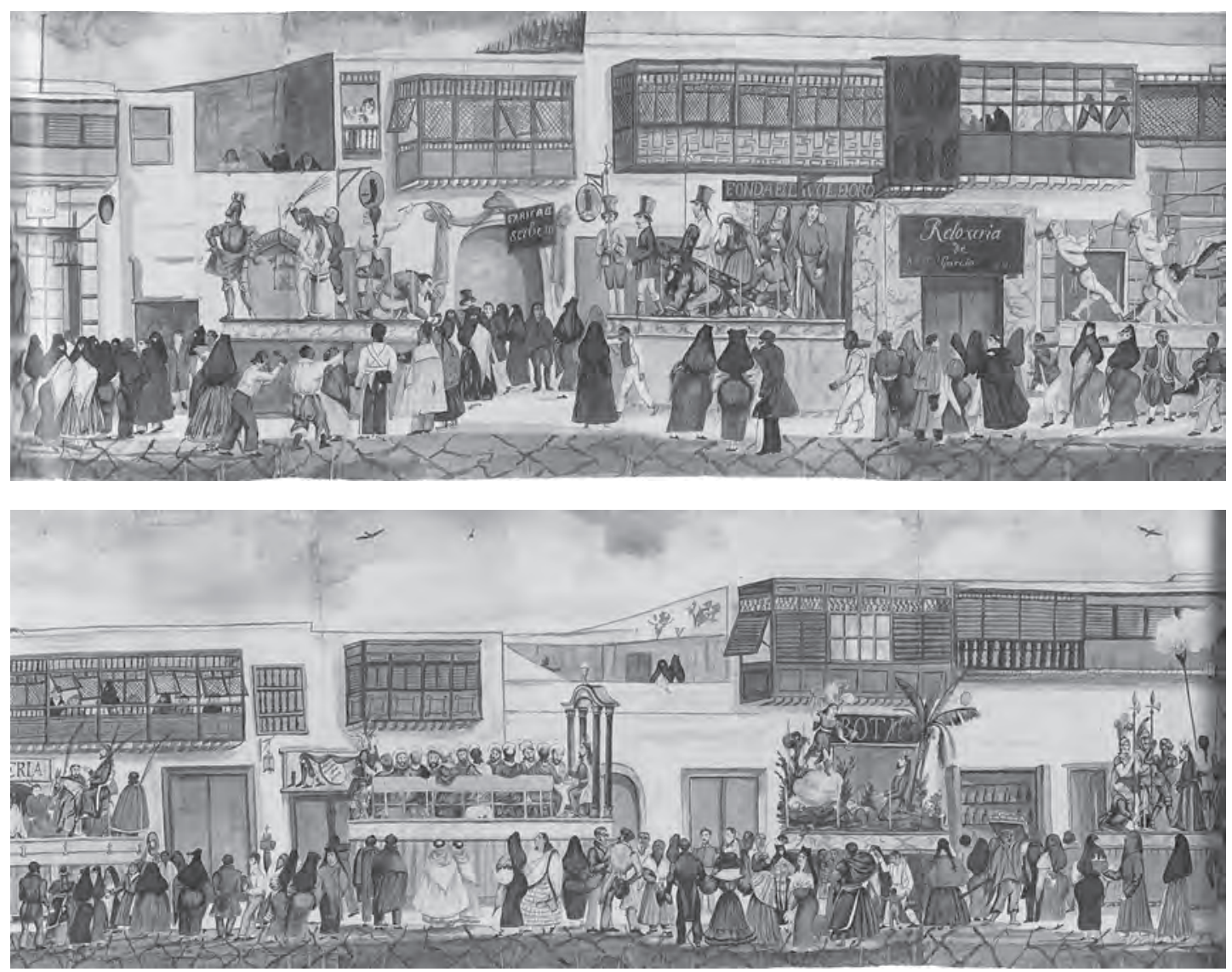

Pancho Fierro, Procesión del Jueves Santo, Colección de la Hispanic Society of America, New York, tomado de Majluf, Natalia y Marcus B. Burke, Tipos del Perú. La Lima criolla de Pancho Fierro. Madrid, Ediciones El Viso, 2008.

sus características socio históricas y culturales, si tomamos en cuenta este principio podemos entender de otra manera los estereotipos y roles asignados a los hombres y las mujeres, las elites y los sectores populares, las personas cultas y analfabetas, ricos y pobres, la fiesta, los espacios sagrados y profanos, entre otros.

Por lo tanto, el cuerpo puede ser una entrada perfecta para estudiar la cultura, la sociedad, la identidad y el género. La historiografía peruana no tiene mucho tiempo en este terreno pero resulta muy atractivo y todo un reto explorar cómo se representa el cuerpo femenino en las acuarelas de Pancho Fierro, sus variantes y complejidades porque reflejan tanto los gustos masculinos del pintor los de sus clientes, en am- bos casos este enfoque permite aproximarnos a los estereotipos sexuales y raciales vigentes en la Lima del Novecientos ${ }^{48}$.

Me atrevería a afirmar que las grandes protagonistas del mundo panchofierrista son las mujeres de origen afro, sus cuerpos son sensuales y generosos que dan placer porque son representadas en contextos muy específicos: siempre están asociadas a la comida, las flores, los licores,

48 En el Perú algunas historiadoras e historiadores están abordando el cuerpo desde la política, las prácticas sociales y culturales, como la pionera María Emma Mannarelli $(1992,1999)$ Ver también Alicia del Águila (2003), Margarita Zegarra (1999, 2001), Jesús Cosamalón (2003), Maribel Arrelucea (2009), Van Deusen (2007). 
la música, la maternidad, los olores y perfumes. La ciudad de Lima y el cuerpo de las mujeres afro descendientes constituyen un gran escenario sensual y festivo, las tapadas, vendedoras, zahumadoras, mixtureras, aparecen continuamente en las acuarelas remarcando el valor del cuerpo de las negras, las mulatas y las zambas.

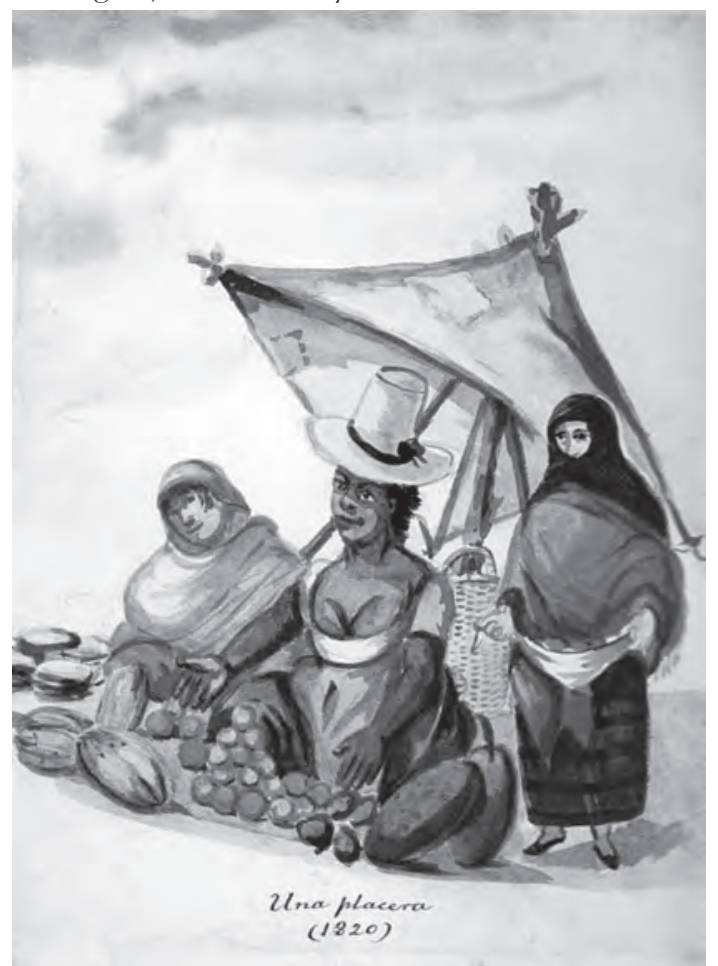

Pancho Fierro, Una placera (1820). Municipalidad de Lima.

Esta es, en mi opinión, una de las acuarelas más bellas de Pancho Fierro, representa tres mujeres en una escena de mercado pero la afro descendiente es la figura principal. La placera ocupa el lugar central flanqueada por dos mujeres cubiertas por capas, con el rostro y cuerpos apenas insinuados, casi sin formas femeninas. En contraste, la afro descendiente es una figura llamativa, su escote deja al descubierto sus senos generosos, su cuerpo está en cuclillas, piernas y brazos abiertos, ofreciendo la mercadería/cuerpo, su rostro es hermoso, mirada y sonrisa pícara, labios rojos. La idea es clara, el cuerpo afro descendiente en el espacio público es tentador. Esto está presente en otras acuarelas, veamos.

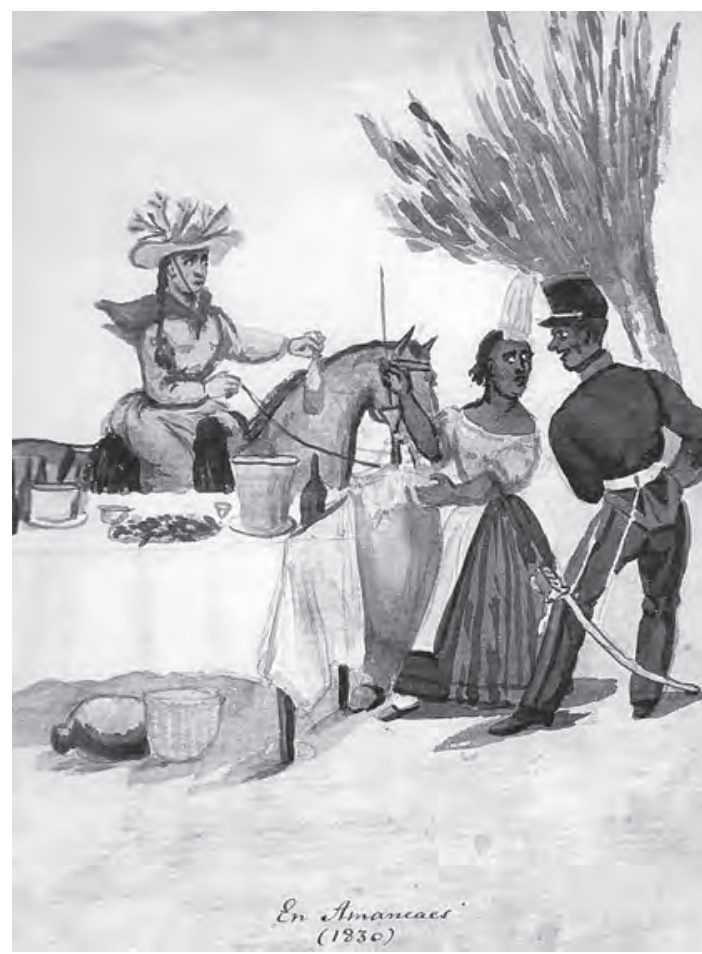

Pancho Fierro, En Amancaes (1830). Municipalidad de Lima.

En esta acuarela hay un triángulo bien interesante, una mujer al margen y una pareja de afro descendientes, podríamos pensar que la figura principal es la primera mujer porque se encuentra en un plano superior, montada a caballo, lleva capa roja al viento y flores amarillas en el sombrero, sin embargo, la figura central es la segunda mujer, está en el plano central, entre la mesa llena de viandas, el licor y el hombre/ cliente. La composición del cuerpo es similar al caso anterior, lleva un escote amplio aunque apenas se insinúan los senos, asoma un pie diminuto calzado y con media blanca. La actitud de los tres personajes evidencia el orden social y sexual, si miramos a la mujer blanca o mestiza, está en actitud de demandar atención pero al mismo tiempo a una distancia prudente mientras la pareja de afro descendientes conforman un espacio aparte, sus miradas se entrecruzan con atención y en el caso del hombre tiene un rostro pícaro al instante de pagar por el licor ofrecido por la afro descendiente. La simbología es muy sutil, para Pancho Fierro y todos sus 
contemporáneos, cada grupo étnico debía mantener un lugar de acuerdo a su "calidad" étnica y socioeconómica, tal como lo hace la mujer a caballo que solo observa la escena, el coqueteo es entre los afro descendientes. Esto también se nota en la siguiente acuarela:

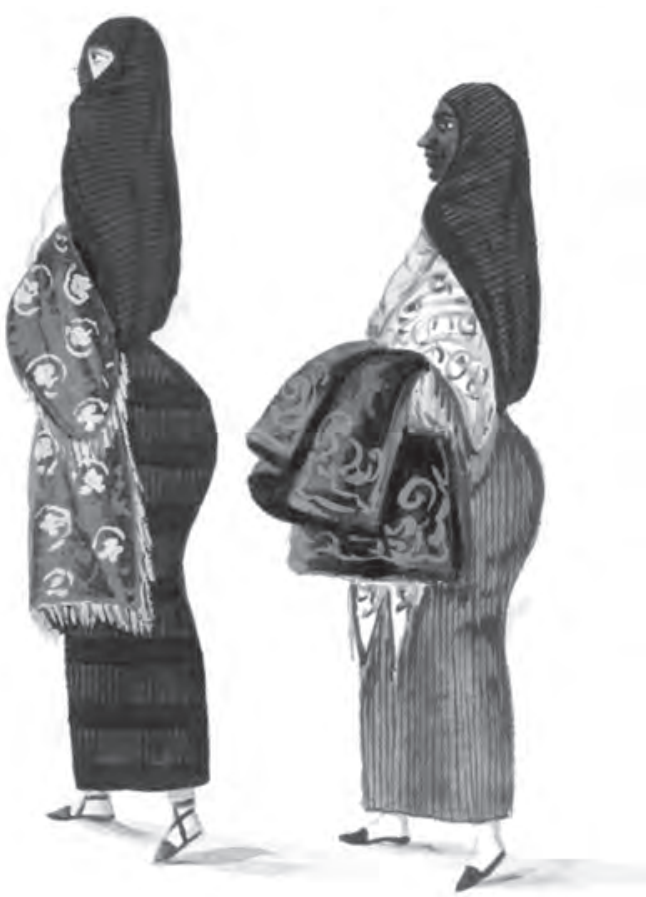

Pancho Fierro, sin titulo, tomado de Majluf, Natalia y Marcus B. Burke, Tipos del Perú. La Lima criolla de Pancho Fierro. Madrid, Ediciones El Viso, 2008.

La pintura representa a dos mujeres, a simple vista son casi iguales, ambas tienen cuerpos voluptuosos, pies diminutos calzados con zapatitos y medias blancas. Sin embargo, en esta acuarela hay todo un episteme de la diferencia de género, clase y etnicidad, para empezar la primera tapada es más alta, camina delante de la otra, sus zapatos son más elegantes con tiras cruzadas y es blanca, a pesar de estar tapada muestra un ojo y parte del rostro. La segunda mujer camina detrás de la primera, es más pequeña, lleva una alfombrita en el brazo que era usado por las mujeres de la elite para arrodillarse en las iglesias, además, la tapada en realidad va destapada mostrando todo el rostro, ardid del pintor que permite descubrir el color de la piel. Señora y sirvienta va juntas, ambas son atractivas, dueñas de cuerpos sensuales, con caderas prominentes pero una es superior y la otra inferior aunque en su inferioridad sigue siendo hermosa. Pancho Fierro utiliza tres recursos para enfatizar en la belleza de la afro descendiente, primero los dos mantones vistosos que porta elegantemente la mujer, segundo las sombras en la falda para insinuar las piernas, pantorrillas, caderas y trasero, como si la tela se pegara al cuerpo dejando al descubierto sus encantos. Tercero, el rostro sereno de perfil, similar a las estatuas de vírgenes, es un rostro bien trazado, bello, con la mirada fija en el horizonte, relajada, contrasta totalmente con el cuerpo sensual..

En las acuarelas aparecen frutas como limones, fresas, granadillas, melones, naranjas, paltas, sandías, papayas, entre otras, que son redondas, jugosas, dulces y perfumadas como el cuerpo femenino. Desde la perspectiva masculina, las mujeres y las frutas están al alcance de la mano, listas para ser saboreadas y consumidas.

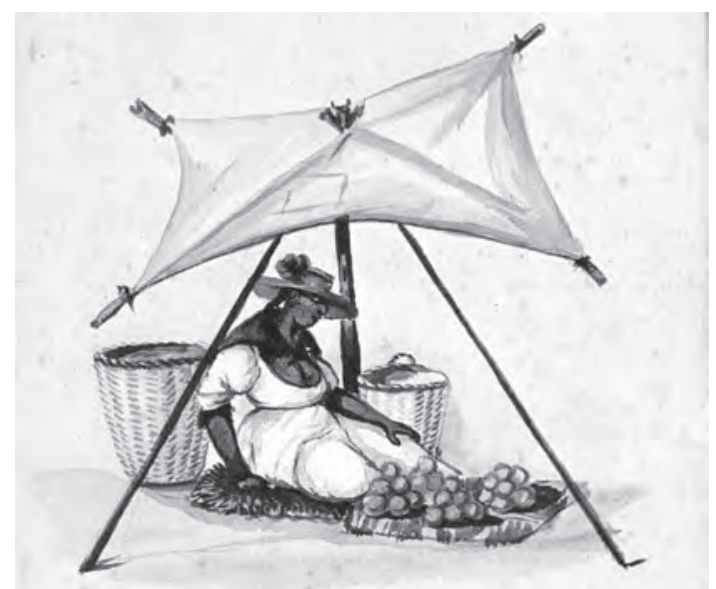

Pancho Fierro, Vendedora, tomado de Cisneros Sánchez, Manuel, Pancho Fierro y la Lima del 800. Lima, Importadora, Exportadora y Librería García Ribeyro SCRL, 1975.

En este caso la mujer se encuentra reclinada sobre un tapete azul, está adornada con sombrero de lazo rojo, lleva puesto un vestido blanco que se pega al cuerpo permitiendo apreciar sus curvas, marca las caderas y piernas, además el escote profundo deja a la vista sus senos. Todo 
el cuerpo trasmite sensualidad, remarcado con el brazo colocado displicentemente en la rodilla, la cabeza ladeada, la mirada hacia la fruta que aparece en el centro del cuerpo, casi a la altura del sexo femenino.

Asimismo, el cuerpo femenino afro se relaciona con la comida y el licor, como el pisco y la chicha, desde los chicharrones, jamones, picantes, cebiche, tamales, humitas, anticuchos, rocotos, así como tradicionales postres, tales como buñuelos, picarones, manjarblanco, bizcochos, mazamorras, los biscochos llamados "Revolución caliente" y turrones. Entre las bebidas, se distingue claramente el pisco, la chicha, la tisana, el ante, la chicha terranova, entre otros. Al igual que la fruta, la comida y el licor están dispuestos para ser consumidos, saboreados, disfrutados.

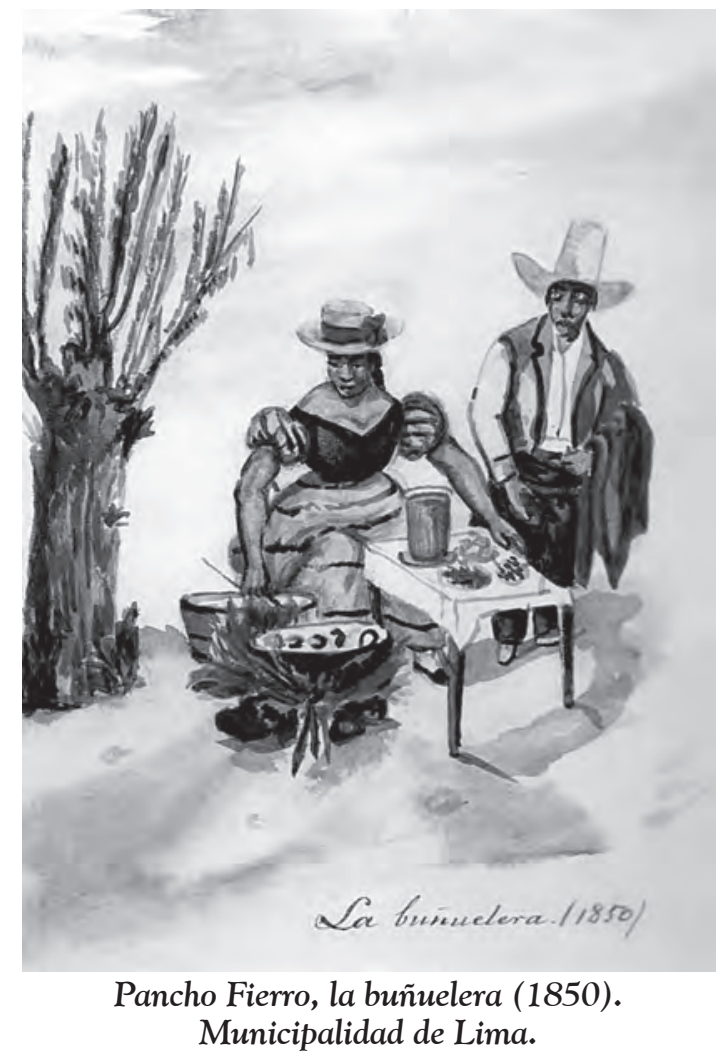

Esta acuarela muestra lo opuesto a lo visto anteriormente. La composición del cuerpo femenino es impecable, muy sensual con el ves- tido a rayas, sombrero con listón rojo y escote profundo que deja ver los senos generosos, ella se encuentra sentada con los brazos abiertos entre el fogón y la mesa con viandas, resulta muy simbólico representarla al lado del fuego fuerte como si el cuerpo femenino fuese la tentación en el espacio público. Sin embargo, su actitud es de contraste, está muy atenta al perol donde se fríen los buñuelos, no mira al hombre/cliente, su brazo está colocado de tal manera que parece una barrera entre ambos.

Las mujeres panchofierristas también son cuerpos que exhalan perfume, son las vendedoras de frutas, flores y mixturas. Las cabezas de las mujeres aparecen adornadas con jazmines, rosas, alhelíes, asimismo sus sombreros, también los caballos, las mesas generosas donde se expende la comida y la bebida.

Existía una larga tradición colonial por las flores y mixturas, iniciando el siglo XIX, W. Stevenson anotó:

"Las mujeres, no contentas con la fragancia natural de las flores, les añaden agua de espliego, sustancia de almizcle o ámbar gris y a menudo la rocían con benzoína, almizcle y ámbar, particularmente la mixtura, formada con jazmines, alelíes, flores de naranja y otros, cortadas de los tallos. Pequeñas manzanas con verdes limones son también mezcladas con tajadas de canela y clavo de especias. La mixtura se halla generalmente en una bandeja sobre el tocador de la dama, la distribuyen a sus amigos pidiéndoles su pañuelo de bolsillo, al que ponen una pequeña cantidad en una esquina, esperando el galanteo, que es lo más delicadamente sazonado" 49 .

Unos años después, Flora Tristán criticó el excesivo perfume de su prima peruana y la de sus compatriotas: "por el perfume que exhala se creería una rodeada de magnolias, rosas, heliotropos y jazmines. Y las flores tan frescas como hermosas que constantemente adornan su cabeza la harían suponer consagradas a su culto" ${ }^{50}$.

Como bien notó Alicia Del Águila, el olor está asociado a la memoria, el recuerdo de una

49 W. Stevenson (1971: 167).

50 Flora Tristán (1982: 155). 
dama era cuidadosamente construido a través de mezclas de olores. ${ }^{51}$ Pero no estamos ante el esfuerzo individual de una "dama", tampoco se trató de una costumbre exclusiva de la elite, las acuarelas de Pancho Fierro demuestran que todas las mujeres eran afectas a las flores, ricas y pobres, nobles y plebeyas, blancas, indias y negras, libres y esclavas.

Los motivos pueden ser totalmente sensuales, un cuerpo perfumado es un cuerpo que atrae, pero, además, debemos considerar otros puntos, por ejemplo, la cultura colonial daba mucha importancia a los adornos y accesorios personales, remarcaban el estatus, la calidad del portador, la situación legal de la persona, mujeres con flores en la cabeza es un aviso de soltería como se observa hasta el día de hoy en las comunidades andinas.

Ricardo Palma notó la relación entre flores y seducción en la tradición "El mes de diciembre en la antigua Lima" refiere: "Las jóvenes solteras se diferenciaban de las casadas en la colocación de las flores que se ponían en el peinado. Era sabido que rosas y claveles, al lado izquierdo, significaban que la propietaria se hallaba en disponibilidad para admitir huésped en el corazón" ${ }^{\text {"52 }}$.

Las acuarelas panchofierristas nos muestran mujeres adornadas con flores en situaciones muy concretas: están vendiendo frutas, comida, licores, están paseando en Amancaes, cabalgando o regresando de Amancaes, son contextos de fiesta y diversión.

Para Pancho Fierro el cuerpo de las mujeres, al igual que la fruta, la comida y la bebida, es una fuente generosa que entrega placer, alimenta, genera perfumes, se mueve ondulantemente en el espacio público, desde allí se inicia la fiesta, la sensualidad, la cadencia que se extiende y domina toda la ciudad imprimiendo un ethos cultural.

No me parece casual la relación entre cuerpo femenino, fiesta, comida y bebida. Las acuarelas de Pancho Fierro deben ser entendidas bajo una lógica ritual, la de la fiesta, un escenario

51 Alicia del Águila (2003: 59).

52 Ricardo Palma (1921: 117). temporal y espacial dentro de la vida cotidiana, no considero que sea paralelo o en un momento aparte, la cultura limeña era de fiesta permanente, cruzaba espacios profanos y sagrados, risa y gravedad, ayuno y banquete, abstinencia y sensualidad. En el caso concreto del cuerpo, la comida y la bebida, están entrelazados y confundidos en una sola esencia porque así era entendido en la cultura festiva limeña. Además, como ya dije anteriormente, la Iglesia autorizó y alentó la religiosidad como espectáculo público, permitía reforzar vínculos, identidades, roles, también jugaba con la permuta de jerarquías -el mundo al revés- la burla y el escarnio, la libertad autorizada y tolerada.

Según Bajtin, las personas en el mundo medieval participaban al mismo tiempo de dos existencias paralelas y separadas: la vida oficial, seria y piadosa y la del carnaval, burlona, profana, material y sensual. ${ }^{53}$ Ricardo Palma también lo notó al describir la fiesta que se armaba frente al altar de la Purísima comentó: "lo religioso y sagrado no excluía a lo mundanal y profano" ${ }^{54}$.

Me parece que el mundo limeño era de carnaval permanente, ambos aspectos se fusionaron con la tolerancia de las autoridades coloniales, luego las republicanas y se mantuvieron hasta bien avanzado el siglo XIX ${ }^{55}$. Este ambiente festivo corresponde a un ethos propio de la sociedad limeña pre moderna, que presenta, empleando el término de Mijail Bajtin, un "humor carnavalesco" es decir, una manifestación colectiva donde todos participan del espectáculo, la risa es general y universal porque el mundo entero parece cómico, relajado, sin contradicciones ${ }^{56}$.

Para Bajtin el humor era, ante todo, patrimonio del "pueblo" pero para el caso peruano tendría que hacer una mayor precisión porque implica usar el concepto de "pueblo" muy alejado del significado burgués, en otras palabras, en la sociedad colonial y decimonónica el pueblo

53 Mijail Bajtin (1974: 90).

54 Ricardo Palma (1921: 119).

55 Sobre la represión a las costumbres limeñas ver Fanni Muñoz (1997) y sobre el carnaval Rolando Rojas (2005).

56 Mijail Bajtin (1974: 17). 


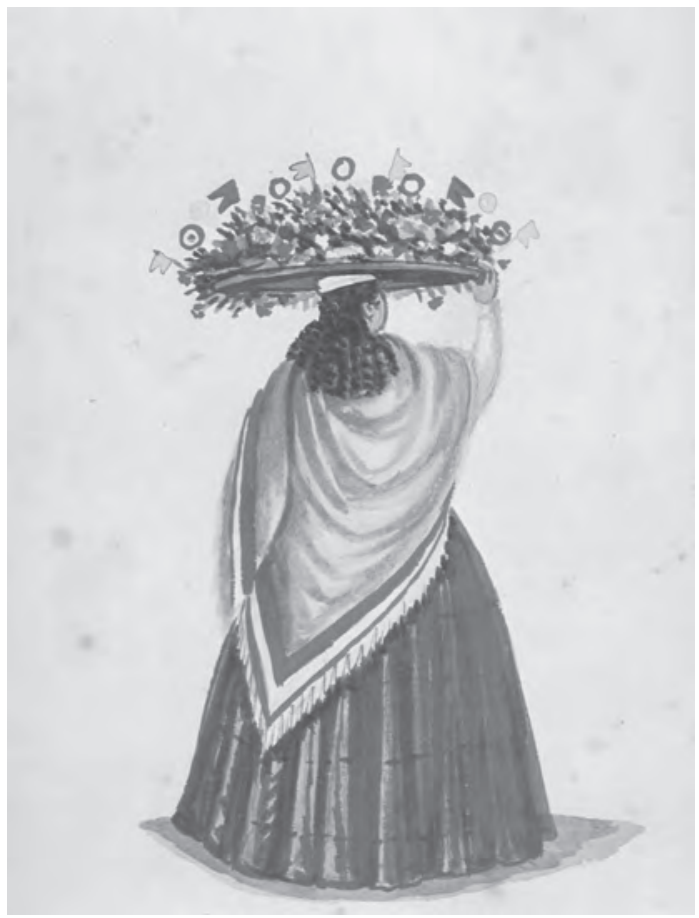

Pancho Fierro, Mixturera, Reproducido en Cisneros Sánchez, Manuel, Pancho Fierro y la Lima del 800. Lima, Importadora, Exportadora y Librería García Ribeyro SCRL, 1975.

era entendido como un conjunto de grupos superiores e inferiores, porque la diferencia social era natural, parte del sistema, en ese sentido cuando se mencionaba "pueblo" se entendía como una sociedad con distintos grupos unidos y separados al mismo tiempo ${ }^{57}$.

Al revisar las acuarelas de Pancho Fierro estoy convencida que nos muestran Lima como el escenario del placer sensorial, de allí que el ambiente de fiesta siempre contenga elementos festivos, carnavalescos, sagrados y profanos al mismo tiempo. Por eso no hay procesión sin comida, mujeres/ cuerpos, flores, cohetecillos, licores y música. Además, nos ayuda a entender las manifestaciones culturales de los limeños y costeños como parte de una larga tradición festiva, una forma de ser específica, una cultura aglutinante, donde se fusionaron los elementos

57 Ver la interesante crítica de Burke al concepto de pueblo y cultura popular. Peter Burke (1991: 35-60).

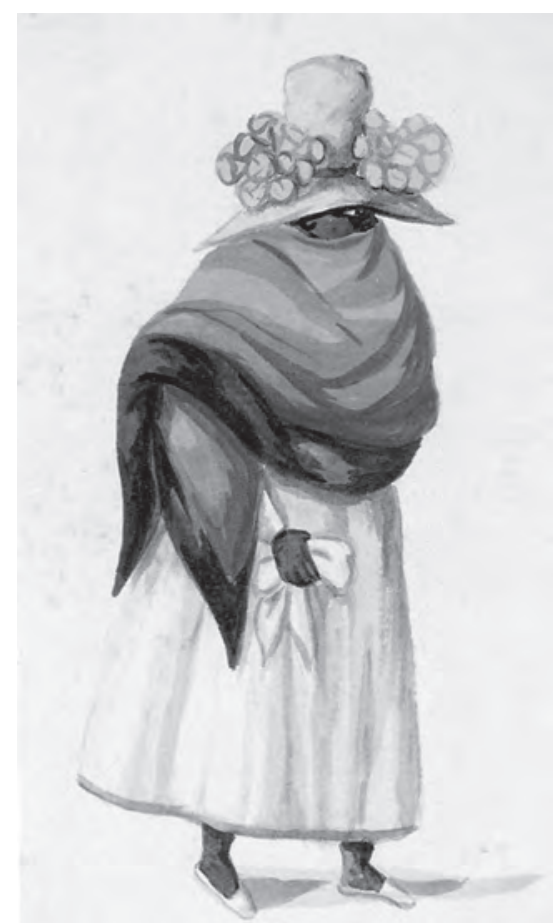

Pancho Fierro, sin titulo, reproducido en Majluf, Natalia y Marcus B. Burke, Tipos del Perú. La Lima criolla de Pancho Fierro. Madrid, Ediciones El Viso, 2008.

andinos, afros e hispanos para dar paso a una identidad criolla, urbana, limeña y costeña que es en esencia multicultural.

\section{Bibliografía}

Acosta, Rosa

1997 Fiestas coloniales urbanas (Lima-CuscoPotosí) Lima: Otorongo.

Álvarez, Gerardo

2001 La difusión del futbol en Lima, Tesis de Licenciatura en Historia, Lima: UNMSM.

Arrelucea Barrantes, Maribel

2009 Replanteando la esclavitud. Estudios de etnicidad y género en Lima borbónica. Lima: CEDET - AECI - Embajada de España - CCE.

Barring, Maruja; Narda Henríquez (Comp.)

1995 Otras pieles. Género, historia y cultura. PUCP. 
Bayly, Jaime

1959 "El artista Pancho Fierro" En Pancho Fierro con cinco reproducciones, Lima: Instituto de Arte Contemporáneo pp. 39-72.

Bajtin, Mijail

1974 La cultura popular en la Edad Media y el Renacimiento. Barcelona: Barral editores.

Bazán, Dora

1967 La mujer en las tradiciones peruanas. Madrid: Maribel, Artes Gráficas.

Bonilla, Heraclio

1974 Guano y burguesía en el Perú. Lima: IEP.

1980 Un siglo a la deriva. Ensayos sobre el Perú, Bolivia y la Guerra. Lima: IEP.

Burke, Peter

1991 La cultura popular en la Europa moderna. Madrid: Alianza editorial.

2001 Visto y no visto. El mundo de las imágenes como documento histórico. Barcelona: Editorial Critica.

Caller Salas, Fernando (editor)

2003 Pancho Fierro. Personajes típicos de Lima (Perú) Acuarelas inéditas. Lima: UNI.

Cantuarias, Ricardo

1995 Pancho Fierro. Colección Forjadores del Perú, volumen 25. Lima: Editorial Brasa S.A.

Castillo, Teófilo

1918 "Pancho Fierro" En Variedades, Lima, 21 de noviembre.

Cisneros Sánchez, Manuel

1975 Pancho Fierro y la Lima del 800. Lima: Importadora, Exportadora y Librería García Ribeyro SCRL.

Collingwood, Robin

1996 [1946] Idea de la Historia. México DF: FCE, Decimonona reimpresión.

Carrió de la Vandera (Seud. Concolocorvo)

1942 [1775 ] El lazarillo de ciegos caminantes desde Buenos Aires hasta Lima. Buenos Aires: Ed. Solar.

Cosamalón, Jesús

1993 "Una visión del cuerpo femenino y de la enfermedad a partir de dos diagnósticos médicos, Lima, 1803" Anuario de Estudios Americanos, Tomo LX, 1, pp. 109-139.

1999 "Descalza de pie y pierna. Una reflexión sobre las preocupaciones por la vestimenta de las limeñas a fines del siglo
XVIII e inicios del XIX". En Zegarra, Margarita (ed.) Mujeres y género en la historia del Perú. Lima: Cendoc-Mujer.

2009 Babel en los Andes. Población y mestizaje en Lima (1860) México D.F. Tesis para optar el grado de Doctor en Historia por el Colegio de México.

2010 "Mestizaje e interrelación social en el tránsito de la sociedad de castas a la república liberal. Lima, 1790-189” Inédito.

Cueto, Marcos

1997 El regreso de las epidemias. Lima: IEP.

Del Águila, Alicia

2003 Los velos y las pieles. Cuerpo, género y reordenamiento social en el Perú republicano. Lima (1822- 1872). Lima: IEP.

Denegri, Francesca

1996 El abanico y la cigarrera. La primera generación de mujeres ilustradas en el Perú. Lima: Flora Tristán ed. IEP.

El Mercurio Peruano

1964 Edición facsimilar, 12 volúmenes, 17911794. Lima: Biblioteca Nacional.

Elías, Norbert

1989 El proceso de la civilización. México DF: FCE.

Elmore, Peter

1993 Las murallas invisibles. Lima y la modernidad en la novela del siglo XX. Lima: Mosca Azul - El Caballo Rojo.

Estenssoro, Juan Carlos

1996 "La plebe ilustrada: el pueblo en las fronteras de la razón”. En Walker, Charles (comp.) Entre la retórica y la insurgencia. Las ideas y los movimientos sociales en los Andes, siglo XVIII. Cusco: Centro de Estudios Regionales Andinos Bartolomé de las Casas, pp. 33-66.

1987 "Estética, música y fiesta: elites y cambio de actitud frente a la cultura popular. Perú, 1750-1850" En Urbano, Henrique (comp.) Tradición y Modernidad en los Andes. Cusco: Centro de Estudios Regionales Andinos Bartolomé de las Casas, pp.181-196.

Ferradas, Lissete Cristina

2009 Los objetos de mi afecto: la importancia del vestuario y los 'trastes mujeriles' en el mundo femenino en Lima de fines del siglo 
XVIII. Tesis de Licenciatura en Historia, Lima: PUCP.

Florez Araoz, José

1975 "Pancho Fierro pintor mulato limeño" Cultura Peruana, V, pp. 20-62.

Frezier, Amadee

1973 "Bocetos de Lima". En Núñez, Estuardo El Perú visto por viajeros. Tomo I. Lima: Ediciones Peisa.

Fuentes, Manuel Atanasio

1867 Lima, apuntes históricos, estadísticos, descriptivos y de costumbres. París: Librería de Fermín Didot.

Gamarra, Luis Abelardo

1899 Rasgos de pluma de El Tunante. Lima: Torres.

1907 Lima, unos cuantos barrios y unos cuantos tipos. Lima, s.p.i.

Ginzburg, Carlo

2000 El queso y los gusanos. El cosmos, según un molinero del siglo XVI. Barcelona: Muchnik editores, cuarta edición.

Haenke, Tadeo (Seud. Felipe Bauzá)

1901 [1790] Descripción del Perú. Lima: Imprenta El Lucero.

Koban, Liuba

2005 "Performar para seguir performando: La cultura fitness" Anthropologica, XXIII, No 23, pp. 151-164.

2003 "La construcción social de los cuerpos o los cuerpos del Capitalismo tardío" Persona, 6, pp. 9-21.

La Gaceta de Lima, 20 de junio de 1756.

La Rosa Toro, Agustín

1871 Geografía del Perú bajo su aspecto físico, fisiocrático y político. Lima: Auber y Compañía Editores.

Laqueur, Thomas

1994 La construcción del sexo. Cuerpo y género desde los griegos hasta Freud. Madrid: Ediciones Cátedra.

Lastarria, José

1851 Cartas sobre Lima. Valparaíso: Imprenta del Comercio.

León y León, Gustavo

2004 Apuntes histórico genealógicos de Francisco Fierro: Pancho Fierro. Lima: Fondo Editorial de la Biblioteca Nacional del Perú.
Lossio, Jorge

2003 Acequias y gallinazos. Salud ambiental en Lima del siglo XIX. Lima: IEP.

Lukin, Boris

2003 "Presencia de Pancho Fierro en la Unión Soviética". En Caller Salas, Fernando (editor) Pancho Fierro. Personajes típicos de Lima (Perú) Acuarelas inéditas. Lima: UNI.

Mc Evoy, Carmen

1994 Un proyecto nacional en el siglo XIX: Manuel Pardo y su visión del Perú. Lima: Pontificia Universidad Católica del Perú.

1997 La utopía republicana. Ideales y realidades en la formación de la cultura política peruana (1871-1919). Lima: PUCP.

Majluf, Natalia

1994 Escultura y espacio público. Lima, 18501879. Lima: IEP.

Majluf, Natalia y Marcus B. Burke

2008 Tipos del Perú. La Lima criolla de Pancho Fierro. Madrid: Ediciones El Viso.

Mannarelli, María Emma

1993 Pecados públicos. La ilegitimidad en Lima, siglo XVII. Lima: Flora Tristán ed.

1999 Limpias y modernas. Género, higiene y cultura en la Lima del novecientos. Lima: Flora Tristán ed.

2004 "Vínculos familiares y fronteras de lo público y privado en Perú". En Rodríguez, Pablo (cood.) La familia en Iberoamérica, 1550-1980, Bogotá: Convenio Andrés Bello, Universidad Externado de Colombia.

Morner, Magnus

1980 Estratificación social Hispanoamérica durante el periodo colonial. Estocolmo.

Müka, Ulrich

2010 Política y burguesía en el Perú. El Partido Civil antes de la Guerra con Chile. Lima: Instituto de Estudios Peruanos, Instituto Francés de Estudios Andinos.

Muñoz, Fanni

2001 Diversiones públicas en Lima, 1890-1920. La experiencia de la Modernidad. Lima: Red para el Desarrollo de las Ciencias Sociales en el Perú.

Oliart, Patricia

1995 "Temidos y despreciados. Raza y género en las representaciones de las clases po- 
pulares limeñas en la literatura del siglo XIX". En Barring y Henriquez (Comp) Otras pieles. Género, historia y cultura, Lima: PUCP, pp. 73-88.

1998 "Poniendo a cada quien en su lugar: estereotipos raciales y sexuales en la Lima del siglo XIX" En Panfichi, Aldo; Gonzalo Portocarrero (Ed.) Mundos interiores. Lima, 1850-1950, Lima: Universidad del Pacífico, pp. 261-288.

Orrego, J.; C. Aljovín; J. López Soria (Comp.)

2009 Las Independencias desde la perspectiva de los actores sociales. PUCP, UNMSM, Organización de Estados Americanos para la Educación, la Ciencia y la Cultura, pp. 217-234.

O’Toole, Rachel

2005 "Castas y representación en Trujillo colonial" En Drinot, Paulo; Leo Garofalo (Ed.) Más allá de la dominación y la resistencia. Estudios de historia peruana, siglos XVI-XX, Lima: IEP, pp. 49-76.

Palma, Ricardo

1983 Tradiciones peruanas. Lima: Enrique Cappeletti editor.

1921 El Palma de la juventud. Selección de tradiciones y poesías, aumentada con diversos escritos que hasta la fecha no habían aparecido en volumen. Contiene reproducciones de las acuarelas de Pancho Fierro. Lima: Librería Francesa y Casa Editorial E. Rosay.

Palma, Angélica

1935 Pancho Fierro, acuarelista limeño. Lima. San Martí y Compañía.

Panfichi, Aldo

2000 "Africanía, barrios populares y cultura criolla a inicios del siglo XX" Rostoroswki, María; Javier Mariategui; et al. Lo africano en la cultura criolla. Lima: Fondo Editorial del Congreso del Perú, pp. 137-158.

Panfichi, Aldo y Felipe Portocarrero (Ed.)

1995 Mundos interiores. Lima 1850-1950. Lima: Centro de Investigación de la Universidad del Pacífico.

Pinto, Ismael

1968 "Pancho Fierro en Rusia" En Expreso, Lima, 11 de marzo de 1968, p. 9.
Poole, Deborah

2000 Visión, raza y modernidad. Una introducción al mundo andino de imágenes. Lima: Sur, Casa de Estudios del Socialismo.

Porras, Raúl

1959 "La Lima de Pancho Fierro" En Pancho Fierro con cinco reproducciones, Lima: Instituto de Arte Contemporáneo, pp. 9-39.

Porras, Raúl y Jaime Bayly

1959 Pancho Fierro con cinco reproducciones. Lima: Instituto de Arte Contemporáneo.

Portal, Ismael

1912 Lima de ayer y de hoy. Lima: H. La Rosa y Compañía.

1919 [1863-1934] Cosas limeñas, historia y costumbres. Lima: Empresa Tipográfica Unión, A. Giacone y Compañía.

1932 Del pasado limeño. Lima: Gil S.A.

Portocarrero, Gonzalo

1998 "El fundamento invisible: función y lugar de las ideas racistas en la República Aristocrática" En Panfichi, Aldo; Gonzalo Portocarrero (Ed.) Mundos interiores. Lima, 1850-1950, Lima: Universidad del Pacífico, pp. 219-260.

Radiguet, Max

1964 Lima y la sociedad peruana. Lima: Biblioteca Nacional del Perú.

Ramón, Gabriel

1999 La muralla y los callejones. Intervención urbana y proyecto político en Lima durante la segunda mitad del siglo XIX. Lima: Sidea y PromPerú.

Rickkets, Mónica

2001 "El teatro en Lima: tribuna política y termómetro de civilización, 1820-1828" En O'Phelan, Scarlett (Comp.) La Independencia del Perú. De los Borbones a Bolivar. Lima: PUCP.

Rivera, María Milagros

1999 Textos y espacios de mujeres (Europa, siglos IV-XV) Barcelona: Icaria.

Rivera Martínez, Edgardo

1969 "Acuarelas desconocidas de Pancho Fierro" En Fénix No. 19, Lima, pp. 167-192.

Rivas, Roberto

2003 "Danzantes negros en el Corpus Christi de Lima, 1756. Vos Estis Corpus Christi 
(1 Cor. XII, 27)" En Carrillo, Ana; Ciro Corilla et al. Etnicidad y discriminación racial en la historia del Perú. Lima: PUCP,IRA, Banco Mundial, pp. 35-64.

Rugendas, Juan Mauricio

1959 [1802-1858] Costumbres sudamericanas (Argentina, Chile, Uruguay. Buenos Aires: Pardo-Emecé.

Rojas, Rolando

2005 Tiempos de carnaval. El ascenso de lo popular a la cultura nacional (Lima, 1822. 1922). Lima: IEP-IFEA.

Sabogal, José

1945 Pancho Fierro, estampas del pintor peruano. Buenos Aires: Editorial Nova.

Salazar Bondy, Sebastián

1954 "Acuarelas de Pancho Fierro y discusión" La Prensa, Lima, 26 de marzo, p. 8, 1954.

1956 "Sobre Pancho Fierro" En La Prensa, Lima, 2 de agosto, p. 8, 1956.

1958 “iPara quién adquirir los Pancho Fierro?" En La Prensa, Lima, 30 de octubre, 1958.

Sennet, Richard

1994 Carne y piedra. El cuerpo y la ciudad en la civilización occidental. Madrid: Alianza Editorial.

Shrenk, Leopoldo

1896 Relación de manuscritos y documentos. San Petersburgo: Academia de Ciencias.

\section{Solórzano, Mónica}

2003 "Negros, mulatos y zambos en las acuarelas de Francisco 'Pancho' Fierro”. En Etnicidad y discriminación racial en la historia del Perú, Lima: PUCP-IRA, Banco Mundial. Tomo II, pp. 165-190.
Stevenson, William Bennet

1971 "Memorias sobre las campañas de San Martín y Cochrane en el Perú". Lima, Colección Documental para la Independencia del Perú, T. XXVII, vol.3.

Stokes, Susan

1987 "Etnicidad y clase social, los afroperuanos de Lima, 1900-1930". En Stein, Steve (Director) Lima Obrera Lima: Ediciones el Virrey.

Terralla y Landa, Esteban

1854 Lima por dentro y fuera. Obra jocosa y divertida, la da a luz Simón Ayanque...París, Mezin, con láminas de Ignacio Merino.

Tschudi, Juan Jacobo

1966 Testimonio del Perú, 1838-1842. Suiza/ Perú, Consejo Económico Consultivo.

Tristán, Flora

1984 Peregrinaciones de una paria. La Habana: Casa de las Américas.

Van Deusen, Nancy

2007 Entre lo sagrado y lo mundano. La práctica institucional y cultural del recogimiento en la Lima virreinal. Lima: Fondo Editorial de la PUCP, IFEA.

Villarán, Acisclo

1878 "Don Francisco Fierro, pintor acuarelista peruano" En Semanario La Broma, no. 13, Lima, 12 de enero de 1878, pp. 101.

Zegarra, Margarita

1999 Mujeres y género en la historia del Perú. Lima: Cendoc-Mujer.

2001 "La construcción de la madre y de la familia sentimental. Una visión del tema a través del Mercurio Peruano" Histórica (Lima), XXV. 1, 2001. 